University of South Carolina

Scholar Commons

$1-1993$

\title{
A History of the Opening Statement From Barristers to Corporate Lawyers: A Case Study of South Carolina
}

W. Lewis Burke

University of South Carolina - Columbia, wlburkej@law.sc.edu

Follow this and additional works at: https://scholarcommons.sc.edu/law_facpub

Part of the Law Commons

\section{Recommended Citation}

W. Lewis Burke, A History of the Opening Statement From Barristers to Corporate Lawyers: A Case Study of South Carolina, 37 Am. J. of Legal History 25 (1993)

This Article is brought to you by the Law School at Scholar Commons. It has been accepted for inclusion in Faculty Publications by an authorized administrator of Scholar Commons. For more information, please contact digres@mailbox.sc.edu. 


\title{
A History of the Opening Statement From Barristers to Corporate Lawyers: A Case Study of South Carolina
}

\author{
by WILLIAM LEWIS BURKE, JR.*
}

\section{INTRODUCTION}

In the modern day jury trial, the opening statement is the initial statement of counsel made before the introduction of evidence. Its purpose "is to inform the jury of the facts relied upon to establish the asserted charge, right of action or defense; to apprise it of the nature of the questions involved; and to enable it at the outset of the case to understand in a general way what the claim is in the case about to be tried." The opening provides the first opportunity for the lawyer to persuade the jury, and many of today's trial advocacy commentators claim that the opening statement is the most important stage in the jury trial. ${ }^{2}$

But the history of the opening statement is obscure. The Second Circuit Court of Appeals has held that there is no constitutional right to make an opening statement, because "there was no settled body of English law concerning opening statements to which the framers of our Constitution....[could] look in 1789." 3 A number of state supreme courts have held that the privilege to make an opening statement is strictly within the discretion of the trial judge. ${ }^{4}$

For many years trial judges in South Carolina refused to allow opening statements, and even today the opening speech in a criminal trial is solely within the judge's discretion. ${ }^{5}$ Erroneous beliefs about

*Professor of Clinical Legal Studies and Associate Dean for Administration, University of South Carolina School of Law. The author wishes to thank his wife, Anne Burke, and his colleagues, Nathan M. Crystal, Vance L. Cowden, Herbert Johnson, William S. McAninch, and Dennis R. Nolan for their valuable suggestions and inexhaustible patience. Also special appreciation is owed to James Bowman for his research and countless hours reading and deciphering old newspapers and records.

1. 2 F. X. BUSCH, LAW AND TACTICS IN JURY TRIALS 265 (1959).

2. See e.g., J. JEANS, TRIAL ADVOCACY 99 (1975); J. MCELHANEY, TRIAL NOTEBOOK 37 (1981).

3. United States v. Salovitz, 701 F.2d 17, 19 (2d Cir. 1983).

4. People v. Barron, 578 P.2d 649, (Colo. 1978); Johnson v. Commonwealth, 111 Va. 877, 69 S.E. 1104 (1911); Juhasz v. Barton, 146 Fla. 484, 1 S.2d 476 (1941); Stewart v. State, 245 Ala. 511,17 S.2d 871 (1944).

5. State v. Brown, 277 S.C. 203,284 S.E.2d 777,778 (1981). 
this important trial procedure abound. For example, in 1949 a state trial judge said that South Carolina was unique in its "time honored practice" of reading the pleadings to the jury in lieu of an opening statement. ${ }^{6}$ Another judge, former Chief Justice Bruce Littlejohn, claimed to have been the first judge to permit the opening statement in South Carolina when he allowed its use in 1955.7 A lawyer opposing its use was quoted by Judge Littlejohn as saying "[w]e inherited our system of jurisprudence from England and such was not permitted in England." 8

The exact opposite was true. By the 1500's the opening statement was an integral part of the jury trial in England. From there it was brought to South Carolina and the other American colonies and used for the next 200 years. But by 1900 the opening statement had been transformed throughout the United States. More strangely the South Carolina bar and the bars of possibly two other states abandoned the opening statement and replaced it with the peculiar practice of reading the pleadings in civil cases or the indictment in criminal cases. ${ }^{9}$

However, in South Carolina no decision, statute, or court rule has ever prohibited the opening statement. In fact, not until 1957 did the South Carolina court rules grant discretion to the trial judge to deny the right to deliver an opening. 10

The misunderstood history of the opening statement has denigrated its value and purpose to the jury in both civil and criminal trials. This article examines the history of the opening statement in England and in South Carolina from colonial times into the 1890's, and explains why it was abandoned.

\section{ENGLISH PRACTICE}

For centuries, the practice of the English bar has been to deliver opening statements in the jury trial. The earliest forms of trial in England date from the medieval period. In A HISTORY OF ENGLISH LAW, Sir William Holdsworth identified four forms of early trials: trial by witnesses, wager of law or compurgation, battle, and ordeal." These medieval trials did not resemble a modern courtroom proceeding and did not have an opening statement by counsel. ${ }^{12}$

6. Lide, "Some 'Uniques' in South Carolina Law," I S.C.L.Q. 209 (1949).

7. B. LITTLEJOHN,LITTLEJOHN'S HALF CENTURY AT THE BENCH AND BAR 71 (1987).

8. Id.

9. These other states were Connecticut and North Carolina. For a fuller discussion of these states see notes 255 and 256 .

10. S.C. CIR. CT. R. 85, S.C. CODE ANN. (Supp. 1960).

11. I HOLDSWORTH 302-312 (1903).

12. Primary sources for a description of these early proceedings are Glanvill and Bracton. See THE TREATISE ON THE LAW AND CUSTOMS OF THE REALM OF COMMONLY CALLED GLANVILL (Hall, ed. 1965) and BRACTON ON THE LAWS AND CUSTOMS OF ENGLAND (Thorne Trans. 1968). 
The transition from the medieval forms to the jury trial was slow. At the end of the twelfth century a body of citizens known as an assize was introduced for deciding civil and criminal proceedings. In contrast to the modern jury trial, the assizes were to reach decisions on the basis of their personal knowledge. It was in these proceedings that a formal introductory stage became part of the trial. There were no lawyers, no sworn witnesses, and no formal opening statements, but the prothonotary or the clerk read the complaint. ${ }^{13}$

By the early fourteenth century, The Mirror of Justices referred to pleaders who spoke for the parties in a suit. ${ }^{14}$ This pleader was an advocate. In the performance of his duties he was "to state [his client's] causes" and was "stating and defending" for hire. Such a pleader may have been the first advocate to deliver an opening speech.

By the fifteenth century the jury emerged and the first definite proof of the opening by counsel appeared. Written about 1470, Sir John Fortescue's treatise, In Praise of the Laws of England, ${ }^{15}$ has been described by S.B. Chrimes as having a "remarkable influence... on...[the] English law of procedure."16 Fortescue documented the use of the opening statement. After the jury was sworn, Fortescue said:

Whychye thynges beinge done eyther party by him selfe or his consellours in the prsense of the courte that utter and open to the saide sworne men all and singular maters and euidences whereby he thynkethe he may best informe them of truethe of the yssue so impleaded. And then may either partie bring before the faire Justices and chozne menne al and singular suche witnesses on his beehalfe as hee will produce. ${ }^{17}$

\section{Bracton provides this description of an assize:}

"When the parties have agreed upon the jurors, the assize will then proceed, and they ought at once to take an oath in this form, the first by these words, 'Hear this, O Justices, that I will speak the truth as to this assize and as to the tenement of which I made the view by order of the lord king, …...After the oath has been taken... let the prothonotary read the substance of the writ for the instruction of the jurors,.... [The justices will here say nothing to instruct the jurors, because nothing is said or excepted against the assize at the beginning.] The oath having been taken, let the jurors retire to some private place and discuss among themselves the matter which they have been enjoined to consider,.." 3 BRACTON 72.

14. 2 A. HORN, THE MIRROR OF JUSTICES 47-48 (Seldon Soc. ed. 1895). Some there be who know not how to state their causes or to defend them in court, and some who cannot, and therefore are pleaders necessary; so that what plaintiffs and others cannot or know not how to do by themselves they may do by their serjeants, proctors, or friends. Pleaders are serjeants wise in the law of the realm who serve the commonalty of the people, stating and defending for hire actions in court for those who have need of them...

15. JOHN FORTESCUE, DE LAUDIBUS LEGUM ANGLIE (S.B. Chrimes ed. 1942) (reprint 1979).

16. Id. at xxix.

17. JOHN FORTESCUE, A LEARNED COMMENDATION OF THE POLITIQUES LAWES OF ENGLAND (Robert Mulcaster trans., London 1567) (emphasis supplied). 
The report of a 1465 trial mirrors Fortescue's description. ${ }^{18}$ Babington $v$. Venor began with the lawyers for both plaintiff and defendant showing evidence in "a long story...." Then "Catesby for the plaintiff," made "counterstatements", and then two defense witnesses testified. "Then Guy Fairfax, counsel for the plaintiff, tells another story as to what took place at the view...." The report concluded with the judge's charge and submission of the case to the jury. 19

Through the sixteenth and the seventeenth centuries there was no mention of the opening statement in the major treatises of the era by Sir Edward Coke and Sir Matthew Hale. ${ }^{20}$ But we know that Coke as Attorney General delivered stirring opening speeches, and the opening had continued little changed since Fortescue. In 1623 Thomas Powell's The Attourneys Academy described "[a]fter the Record is read, The Counsaile are to say what they can for their Clyents, severally and respectiuely. Then the Witnesses in the matter are to bee produced, sworne, and examined at the Barre...."n1

A cursory sampling of early seventeenth century trial records reveals opening speeches by counsel. In the trial of Sir Walter Raleigh in 1603, ${ }^{22}$ the indictment for high treason was read, to which Raleigh pleaded not guilty. The King's Serjeant, Heale, opened the crown's case with a short explanation of the indictment, and the Attorney General, Sir Edward Coke, delivered a long opening speech. ${ }^{23}$

Following a short explanation of the facts, in the 1606 trial of Guy Fawkes and others for the Gunpowder Plot, the Attorney General, Sir Edward Coke, began his opening by announcing "that these are the greatest treasons that ever were plotted in England, and concern the greatest king that ever was of England. ${ }^{24}$ The same procedure of opening the cases was used in the 1661 John James treason trial, 25 and the 1662 trial of Thomas Tonge, et al, for conspiring to kill Charles II. ${ }^{26}$

18. J. THAYER, A PRELIMINARY TREATISE ON EVIDENCE AT THE COMMON LAW 133-134 (1898).

19. Id.

20. See EDWARD COKE, THE FIRST PART OF THE INSTITUTES OF THE LAWES OF ENGLAND (London 1628) (Garland reprint 1979) and THE FOURTH PART OF THE INSTITUTES OF THE LAWES OF ENGLAND (London 1797), and MATTHEW HALE, THE HISTORY OF THE COMMON LAW OF ENGLAND (4th ed. Dublin 1792) and THE HISTORY OF THE PLEAS OF THE CROWN (London 1797). 1974).

21. T. POWELL, THE ATTOURNEYS ACADEMY 120 (London 1623) (reprint

22. 2 HOWELL'S STATE TRIALS 2 (1603).

23. Id. at 5 .

24. 2 HOWELLS STATE TRIALS 159 at 166.

25. 6 HOWELL'S STATE TRIALS 67, 76.

26. Id. at 225 . 
The only seventeenth century civil jury trial included in HOWELL'S STATE TRIALS was between Sir William Pritchard, the Lord Mayor of London, and Thomas Papillon, for a false arrest, on November 6, 1684.27 The Pritchard case illustrates the practice by which the case was opened by speeches of a junior and a lead counsel. The first speech for the plaintiff was by the junior counsel who opened on the pleadings, and concluded with the issues. Then the lead counsel opened with the facts. ${ }^{28}$ After the plaintiff's witnesses testified, the three defense lawyers made opening speeches before calling their witnesses.

In the eighteenth century the great commentator on the English law was Sir William Blackstone. ${ }^{29}$ Blackstone's Commentaries on the Laws of England, published in 1765, had a profound impact, both in England and America.

Blackstone gave a clear description of an opening in a jury trial:

The jury are now ready to hear the merits; and, to fix their attention the closer to the facts which they are impaneled and sworn to try, the pleadings are opened to them by counsel on that side, which holds the affirmative of the question in issue. For the issue is said to lie, and proof is always first required, upon that side which affirms the matter in question...The opening counsel briefly informs them what has been transacted in the court above; the parties, the nature of the action, the declaration, the plea, replication, and other proceedings, and, lastly, upon what point the issue is joined, which is there set down to be determined. ...The nature of the case, and the evidence intended to be produced, are next laid before them by counsel also on the same side: and when their evidence is gone through, the advocate on the other side opens the adverse case, and supports it by evidence; and then the party which began is heard by way of reply. ${ }^{30}$

\section{10 HOWELL 320.}

28. See 3 J. CHITTY, THE PRACTICE OF THE LAW (1836). Chitty provides some understanding of the thought behind the English practice:

The province of the Junior is to state or open, as it is technically termed, the pleadings, and which he should do concisely, but very distinctly and perspicuously; and when they are long or complex, he may properly close his statement with an enumeration of the precise issues to be tried...But the junior should in no case state any fact, or attempt to encroach on the department of the leader, even in a single sentence.

Id. at 877-78; and,

The opening speech is so entirely in the discretion of the leading counsel, and it is so important for the interest of the client that he should be very rarely interrupted....

Id. at 880 .

29. Maitland has said, "[t]wice in the history of English law has an Englishman had the motive, the courage, the power, to write a great, readable, reasonable book about English law as a whole. First it was Bracton, and five hund red years later Blackstone." Quoted by THEODORE F. T. PLUCKNETT, A CONCISE HISTORY OF THE COMMON LAW 286 (1956).

30. 3 W. BLACKSTONE, COMMENTARIES ON THE LAWS OF ENGLAND 366-67 citing Fortescue c. 26 (1326) as to the former practice. Modern English practice remains remarkably similar to that described by Blackstone in both structure and content of the opening. See BUSCH, supra note 1 at 781 . 
The eighteenth century civil cases from HOWELL'S also included opening speeches. ${ }^{31}$ The 1763 case of Wilkes $v$. Wood $^{32}$ at Westminster provides evidence that the contemporary trial practice was identical to that described by Blackstone.

Not until the eighteenth century did criminal defense lawyers make their appearance. Beattie found counsel in criminal trials as early as 1732 , and by the 1740 's they were commonly used..$^{33}$ Although an English statute did not allow defense counsel to address the jury until $1836,{ }^{34}$ the evidence from the trials suggests that the statute merely followed an accomplished practice. 35

The 1754 trial of Elizabeth Canning for perjury comes from a full shorthand transcription. ${ }^{36}$ The indictment was read, followed by the short explanation of the indictment by Mr. Gascoyne, counsel for the king. ${ }^{37}$ Next, Mr. Davy, counsel for the prosecution, opened by describing the evidence. ${ }^{38} \mathrm{He}$ was followed by Mr. Willes, counsel for the crown in the case. ${ }^{39}$ After the prosecution's witnesses testified, Mr. Morton and Mr. Nares opened for the defense with long speechs, reviewing the prosecution's evidence. 40 A similar trial structure was reported in the 1753 forgery trial of Timothy Murphy41, the 1758 blackmail trial of William Barnard, ${ }^{42}$ and the 1759 murder trial of John Stevenson. ${ }^{43}$

The eighteenth century evidence is clear. Blackstone said the practice was to deliver an opening speech, and in the readily available civil trials opening speechs were delivered. In criminal trials, both the prosecutors and the defense lawyers made opening speeches. Even if these infamous trials were not typical, they illustrate that the best barristers gave opening speeches. Was this practice brought to the colonies?

31. The King against Gibbon, 17 HOWELL 802 (1734); Richard Ellis case id. at 822; and Moore agsint the Mayor, et al., id. at 845.

32. 19 HOWELL 1153.

33. J. M. BEATTIE, CRIME AND THE COURTS IN ENGLAND: 1660-1800 356 (1986).

34. 6 \& 7 William (Gulielmi)IV CAP. CXIV (August 20, 1836). See also W. S. McAninch, "Criminal Procedure and the South Carolina Jury Act of 1731," SOUTH CAROLINA LEGAL HISTORY 179 (Herbert S. Johnson,ed. 1980).

35. See BEATTIE, id. at 359 , and the trials cited infra.

36. Id . at 283.

37. Id. at 297.

38. Id. at 298.

39. Id. at 311.

40. Id. at 431 and 451.

41. Id. at 693.

42. Id. at 815 .

43. Id. at 845 . 


\section{COLONIAL SOUTH CAROLINA}

In 1669 the Fundamental Constitutions of Carolina prohibited lawyers, declaring it a "base and vile thing, to plead for money, or reward...."44 However, this experiment was soon abandoned, and by the time BLACKSTONE'S COMMENTARIES were published in 1765, the colony may already have had lawyers for more than seventy years. The first lawyers were Englishmen, trained in England, and naturally followed the English practice.

Some historians consider Nicholas Trott the first practicing lawyer in South Carolina, but Hoyt P. Canady quotes Trott as saying there was one other lawyer in South Carolina when he arrived in 1699.45 Canady speculated that the other lawyer may have been Henry Wigington. In fact, there may have been a practicing bar as early as 1693. After a term of Common Pleas court was held in Charleston in 1693, a statute was enacted prescribing the fees lawyers could charge for appearances before the Court of Common Pleas and the Chancery Court. 46

The earliest South Carolina trial reports are the 1718 piracy trials of Stede Bonnet and others. ${ }^{47}$ The first trial was on October 30, 1718. After the jury was sworn and the indictment read, the Attorney General, Richard Allein ${ }^{48}$, delivered an opening address laced with argument. After Allein's speech, Thomas Hepworth began more impartially, but ended by telling the jury "We shall now call our witnesses, who will state to you what enormous and horrid crimes the prisoners at the bar have committed in the prosecution of the fact laid in the Indictment." 49 After the prosecution's evidence, the prisoners, none of whom were allowed counsel ${ }^{50}$, made brief statements. The Attorney General then delivered a one sentence closing, telling the jury that the

44. Section 70 of the Fundamental Constitutions of 1669 provided:

nor shall any one...be permitted to plead another man's cause, till before the Judge, in open court, he hath taken an oath that he doth not plead for money or reward, nor hath, nor will receive, nor directly, nor indirectly, bargained with the party whose cause he is going to plead, for money, or any other reward....

45. H. CANADY, GENTLEMEN OF THE BAR: LAWYERS IN COLONIAL SOUTH CAROLINA, 251, 253 (1987).

46. "An Act for Ascertaining Publique Officers Fees" Id. at 255.

47. 15 HOWELL'S 1231 (1812).

48. Allein was a practcing attorney who had a temporary commssions as Attorney General in 1718-1719. See W. EDGAR AND N. BAILEY, 2 BIOGRAPHICAL DIRECTORY OF THE SOUTH CAROLINA HOUSE OF REPRESENTATIVES 30 (1977).

49. Id. at 1249.

50. In keeping with the English practice defendants were not allowed counsel except in cases of treason. See discussion at note 47. 
evidence was plain and that the prisoners were pirates. Judge Trott delivered a very brief charge. The defendants were convicted.

The Trial of Major Stede Bonnet on November 10, 1718 began with a reference to the indictments and a not guilty plea by Bonnet. After the jury was sworn, Mr. Hepworth ${ }^{51}$ delivered an impassioned opening speech.52 After the state's evidence, Bonnet made a statement but did not present any evidence. In the other piracy trials that followed, there were openings by the Attorney General and Hepworth with no evidence or statements by any of the prisoners.

These piracy trials offer view, albeit limited, of colonial practice in South Carolina. Some evidence suggests that the practice was similar in other American colonies, where some trials featured opening speeches for the prosecution, ${ }^{53}$ and for the defense. ${ }^{54}$ But with such a dearth of South Carolina evidence, it is incumbent to determine from other sources how strong was the influence of English law on the South Carolina bar and judiciary.

Rule 24 of the Rules and Orders of the South Carolina Court of Common Pleas, promulgated on July 4, 1758, provided that "the same method and practice as in the Court of Common Pleas at Westminster, shall be used and practised here, so far as the same be not repugnant, or contrary to the above Rules. '55 As noted above in

51 Thomas Hepworth was in South Carolina by February 4, 1701. He was one of six practicing attorneys in Proprietary South Carolina. 2 BIOGRAPHICAL DIRECTORY OF SOUTH CAROLINA HOUSE OF REPRESENTATIVES 313.

52. The flavor of the first recorded South Carolina opening speech can be had from the following excerpt:

May it please your Honors, and you, gentlemen of the jury, the prisoner who now stands arraigned at the bar, has been guilty of many piracies, committed many robberies, ruined many families, and been the occasion of many most cruel and inhuman murders, and all that within a very short time past. Should

I here descend into all the particulars, I shall take up too much of your time.... 15 HOWELL 1249.

53. Trial of Nicholas Bayard for High Treason, New York City, 1702, 10 AMERICAN STATE TRIALS 518, 525 (Lawson, ed., reprint 1972) (hereinafter trials from this collection will be cited as Am. St. Tr. followed by a parenthetical reference to the place and date of the trial); Trial of John Quelch for Piracy, 5 Am.St.Tr. 330, 332-33 (Mass. 1704); Trial of John Ury for Inciting Slaves, 1 Am. St. Tr. 114 (N.Y. 1741), and Trial of William Wemms and Seven other British Soldiers for the Murder of Crispus Attucks, 10 Am. St. Tr. 415, 432-445 (Mass. 1770).

54. Trial of Thomas Maule for Slander and Blasphemy, 5 Am. St. Tr. 85, 87 (Mass. 1696); Trial of Nicholas Bayard, 10 Am. St. Tr. 518 (N.Y. 1702); Trial of John Quelch, 5 Am. St. Tr. 330, 334 (Mass. 1704); and Trial of William Wemms and Seven other British Soldiers for the Murder of Crispus Attucks, 10 Am. St. Tr. 415, 432-445 (Mass. 1770).

55. MILLER S COMPILATION FOR THE USE OF THE SOUTH CAROLINA LAW OFFICER, RULES OF COURT, FEE BILLS AND USEFULL FORMS (Charleston 1848). An act of 1768 provided that the practice at Common Pleas and General Sessions "shall be modeled on that of the Courts of Nisi Prius in England..." A.A. 1768, VII, 200, 3. J. PETIGRU, A PORTION OF THE CODE OF STATUTE LAW OF SOUTH CAROLINA 219 (Charleston 1860). 
the case of Wilkes $v$. Wood, the practice at Common Pleas in Westminster in 1763 was for both parties' counsel to deliver opening statements.

Both the English Inns of Court and Blackstone had a greater impact on South Carolina's bar than on the bars of any other colony. South Carolina had a higher population of attorneys with Inns of Court training than did any other colony. ${ }^{56}$ Roscoe Pound described the early South Carolina bar as "the best educated bar in America, both generally and in the law." 57 Of the 58 lawyers admitted before the Revolutionary War, 47 had been educated in the Inns of Court in London. ${ }^{88}$ "Of the thirty or so lawyers who at the time of the Revolution were still in active practice in Charleston, no less than 24 had been educated in the Inns of Court.....59 E. Alfred Jones, in his American Members of the Inns of Court, listed 37 South Carolinians who studied at Middle Temple.

The Middle Temple was the Inn where Blackstone studied in 1741.60 Many of the South Carolinians who studied in England completed the full five years residence required at the Inn and were admitted to the bar in England before their return to South Carolina ${ }^{61}$ John Rutledge bragged to his mother that he not only had been admitted to practice at the Middle Temple, but also "had tried two cases there as a barrister and won them." ${ }^{\prime 2}$ The English legal profession was and still is divided between solicitors and barristers. ${ }^{63}$ Barristers were the trial lawyers. The Inns were exclusively for the training of barristers, so the vast majority of lawyers in Colonial South Carolina were trained as trial lawyers. Many historians have criticized the education at the Inns in the late $1700^{\prime}$ 's for its laxness. ${ }^{64}$ However, leading lawyers such as Charles

56. H. CANADY, GENTLEMEN OF THE BAR: LAWYERS IN COLONIAL SOUTH CAROLINA 18 (1987). "From the founding of the colony until 1780 , seventytwo South Carolinians received some legal training at the Inns of Court. This number comprises 43 percent of the colony's bench and bar which numbered 166 during the colonial period...." Id. at 212 .

57. R. POUND, THE LAWYER FROM ANTIQUITY TO MODERN TIMES 153 (1953).

58. Id. at 304.

59. A. CHROUST, THE RISE AND FALL OF THE LEGAL PROFESSION IN AMERICA 303 (1965).

60. Holdsworth, "Some Aspects of Blackstone and His Commentaries", 4 CAMB. L.J. 261 (1932).

61. See the biographies of Charles Cotesworth Pinckney, James Moultrie, Thomas Heyward, Edward Rutledge, John Rutledge, and William Drayton in 2 BIOGRAPHICAL DIRECTORY OF THE SOUTH CAROLINA HOUSE OF REPRESENTATIVES.

62. R. BARRY, MR. RUTLEDGE OF SOUTH CAROLINA 27 (1942).

63. In the late 1700 's the profession was even more divided than today. The rough divisions were barristers, attorneys, pleaders and conveyancers and the various ranks of the King's representatives including the premier serjeant, antient serjeant, advocate general, attorney general, solicitor general, king's serjeants, king's counsel, and serjeants at law. See 6 HOLDSWORTH $431-457$ and 12 HOLDSWORTH 4. (1938).

64. See, e.g., 7 W. HOLDSWORTH, A HISTORY OF ENGLISH LAW 15-17 
Cotesworth Pinckney attended lectures by Blackstone ${ }^{65}$, and the conscientious students attended sessions of court and observed the great English barristers. ${ }^{66}$ William Loughton Smith's one remaining notebook from his student days recorded attendance at court to hear the decisions of Lord Mansfield and the arguments of Dunning and Erskine. ${ }^{67}$ One such trial was the 1781 trial of George Gordon, Lord Byron, for high treason, in which Thomas Erskine was one of the defense counsel. 68 In this trial, both the prosecution and the defense delivered opening speeches. Citing "precedent for it in the State Trials..." Erskine sought and was granted permission to deliver his address after the close of the defense evidence. ${ }^{69}$ Clearly the great Erskine recognized the impact of closing argument on the jury, but since he had to obtain permission to make a closing speech, we may infer that the opening speech was regarded as the important counsel speech.

Of greater influence on South Carolina practice was Blackstone. In his study of the intellectual impact of Blackstone, Professor Dennis Nolan has concluded that "the law which America adopted was the English Common law as it was interpreted and described by Blackstone. ${ }^{70}$ Similarly, the significance of Blackstone to the South Carolina bar and its practice cannot be understated. Of the original American edition of the Commentaries published in 1771-1772, 89 copies were ordered by residents of Charleston, S.C. ${ }^{71}$ Professor Herbert A. Johnson concluded that eighteenth century American lawyers purchased treatises like Blackstone for utilitarian purposes. ${ }^{72}$ At least one leading South Carolina lawyer, Charles Cotesworth Pinckney, attended Blackstone's lectures and reportedly took four volumes of notes. ${ }^{73}$ One study has examined the reports of South Carolina Courts of Law in the period from 1783 to 1796 and notes that the court cited Blackstone

65 D. MORGAN, JUSTICE WILLIAM JOHNSON 21 (1954). Justice Johnson studied law under Pinckney.

66. John Rutledge advised his younger brother, Edward, to attend the sittings at Nisi Prius at London and Westminster. Letter of July 30, 1769 cited in $2 \mathrm{~J}$. O'NEALL, BENCH AND BAR OF SOUTH CAROLINA, 121 (Charleston 1859).

67. G. ROGERS, EVOLUTION OF A FEDERALIST 92 (1962).

68. 21 HOWELL 486.

69. Id. at 562 .

70. Nolan, "Sir William Blackstone and the New American Republic: A Study of Intellectual Impact," 51 N.Y.U.L.R. 731 (1976).

71. C. WARREN, A HISTORY OF THE AMERICAN BAR 178 (1911). This was second only to 239 for Boston and more than the 60 for New York. See also D. Senese, Legal Thought In S.C. 1800-1860, (Ph.D. dissertation) (1970).

72. H. JOHNSON, IMPORTED 18TH CENTURY LAW TREATISES IN AMERICAN LIBRARIES 1700-1799 at ix, xiv (1978).

73. M. ZAHNISTER, CHARLES COTESWORTH PINCKNEY 17 (1967). This book includes a good description of the type of education one received at the Inns. 
"with especial frequency...."74 The trial arguments from early South Carolina also frequently included references to Blackstone. ${ }^{75}$ As late as 1837, Rule 91 of the South Carolina Law Court of Appeals recommended to law students the reading of Blackstone.

The evidence of the trial practice from the Colonial period in South Carolina consists of the piracy trial transcripts, a court rule, the practice at Westminster, the observations of a South Carolina law student, and of course, Blackstone. Although not voluminous, this evidence does support the contention that the practice of trial lawyers in Colonial South Carolina was to deliver an opening statement before the introduction of evidence.

\section{SOUTH CAROLINA FROM 1792 TO 1860}

After the Revolution, the evidence from early South Carolina cases, court rules, and pamphlet reports of jury trials removes any doubt that the early South Carolina bar used the opening statement.

In the 1792 case of McKenzie against Milligan, ${ }^{76}$ the South Carolina Court of Common Pleas said "[a]fter hearing counsel, the court resolved, that as the defendant made himself, by his plea, the plaintiff in the action, he had a right to proceed and open his case, call his witnesses and conclude it." 77 The McKenzie court was careful to divide the plaintiff's right into three parts. First, the plaintiff had the "right to proceed and open his case." As we have seen, from the time of Fortescue on, the term "open" had referred to the right to deliver an opening statement. Second, the plaintiff was to "call his witnesses." If the term "open" had referred to the right only to present evidence, there would have no need to delineate the right to "call his witnesses." Third, the plaintiff had the right to "conclude it," by making the last argument.

Rule 55 of the Court of Common Pleas, promulgated on July 1,1800 , provided that

On all rules to shew cause, the party called on shall begin and end his cause, and on all special matters, either springing out of a cause at issue, or otherwise, the actor or party submitting a point to the Court, shall in like manner begin and close; and so shall a defendant, who admits the plaintiffs case, and takes upon himself the burden of the proof, have the like privilege. ${ }^{78}$

74. Harrison, "A Study of the Earliest Reported Decisions of the South Carolina Courts of Law", 16 AM. J. OF LEGAL HISTORY 51 (1972).

75. For example, see the argument of Attorney General Robert Y. Hayne in $M$. STROBEL, A REPORT OF THE TRIAL OF MICHAEL AND MARTIN TOOHEY 6 (Charleston 1819).

76. 1 Bay, 248 (S.C. Circuit Ct. 1792).

77. Id. at 248 citing 2 LILL. PRACT. REG. 523. tit. Son Assault. Language similar to that from McKenzie is found in Anonymous, 1 Hill 251 (S.C. Law 1833) interpreting the rule that "the plaintiff is to begin and give evidence.

78. MILLER S COMPILATION at 18. 
The 1838 case of Johnson v. Wideman ${ }^{79}$ clearly interpreted the rule as allowing counsel to deliver an opening statement or argument. In Johnson the plaintiff appealed because "the presiding Judge held that upon the defendant's admitting the note on which the action was brought, he was entitled to begin and conclude by evidence and argument and it was irregular for the plaintiff's counsel to make remarks to the jury introductory to the plaintiff's case." 80 The Court of Appeals in Law ordered a new trial because the right to begin meant the right to make introductory remarks before introduction of evidence.

Other cases from the period used the term "begin" to refer to arguments by counsel. ${ }^{81}$ By the end of the century, the term may have meant the first argument delivered after all the evidence, but in the first half of the nineteenth century, the term referred to the right to make an opening statement prior to presentation of evidence.

The 1852 Moses v. Gatewood ${ }^{82}$ case demonstrates that in court decisions and rules, the South Carolina courts were still following the English practice. In interpreting the court's rule, Judge Wardlaw referred to it as the right to begin argument, and he cited several supporting English authorities. ${ }^{83} \mathrm{He}$ then concluded "[i]n our Court the general rule, as it formerly prevailed in England, has long been established by rule of Court, and is contained in the revised rules which were adopted in 1837. ${ }^{\circ} 4$

These early cases are authority for the conclusion that there was a right to make an opening speech. An examination of the few trial records from the period supports this conclusion.

The earliest post-Colonial trial reports are from verbatim accounts of two 1804 Charleston murder trials produced in pamphlet form by

79. 1 Dud 325, at 326 (S.C. 1838).

$80 \mathrm{Id}$. at 326. (emphasis supplied). The decision interpreted Rule 62 which is identical to Rule 55 of 1800 .

81 Southerlin v. M'kinney, I Rice 35 (1838) Appeal from decision of ordinary to Court of Common Pleas, heard before Evans, J. at Greenville, Fall term, 1838, where appellants were ruled the actors "and entitled to open the case, and to reply, both in evidence and argument." The court held, "[b]y the $62 \mathrm{~d}$ rule of court and the uniform practice in the trial of issues, the party affirming the question must begin, and is entitled to close the case." This was followed in Tillman v. Hatcher,Rice, 271 (S.C. 1839) which referred to the right as "the right of opening and replying in evidence and argument..."

825 Rich. 234 (S.C. 1852) Before O'Neall, Evans, Wardlaw, Frost, and Withers with Whitner, absent.) Petigru represented the respondent.

83 Citing 3 CHIT. GEN. PRAC. 872; Coton vs. James, 1 Mood \& Malk. 275; 22 Eng. C.L.R. 305, Carter vs. Jones, 6 Car. \& P. 64; 25 Eng. C.L.R. 283, Id. at 235236.

84 Id. at 237. In 1837, Rule 55 was renumbered 62. See MILLER'S COMPILATION 42.

85 S. CARPENTER, REPORT OF THE TRIAL OF RICHARD DENNIS, THE YOUNGER, FOR THE MURDER OF JAMES SHAW ON THE 2OTH OF AUGUST, 1804 (Charleston 1805). 
an itinerant stenographer, S. C. Carpenter. On August 20, 1804, Richard Dennis was tried for murder before Judge Elihu Bay. ${ }^{85}$ After listing the jury, Carpenter began his account of the trial with the opening statement of William Loughton Smith. Smith, who was educated at the Middle Temple and had observed the courtroom prowess of Erskine in the trial of Byron ${ }^{86}$, began with an explanation of why, as a private attorney, he was helping with the prosecution. ${ }^{87}$

Smith continued with an eloquent introduction on the duty of the jury. ${ }^{88} \mathrm{He}$ then discussed the indictment, the nature of the crime and the youth of the accused. He anticipated the defense counsel playing upon the jury's sympathy and the asked them to, "banish from your minds every sentiment which may have already obtruded itself, in relation to this lamentable event." 89 Before concluding with an argument on the law and the duty of the jury, he cited and read cases and treatises. After the opening by Smith, the Attorney General ${ }^{90}$ called the first witness for the prosecution.

After the prosecution's case, Keating Lewis Simons ${ }^{91}$ delivered an eloquent opening. After the defense evidence, four defense lawyers made closing arguments. ${ }^{92}$ Then the Attorney General made his reply. ${ }^{93}$

86 Unlike some South Carolina lawyers educated in England, Smith had not been admitted as a Barrister because he refused to take an oath of allegiance to the British crown. See 3 THE WRITINGS OF B.F. PERRY 282 (1889) (Meats and Anold ed. 1980).

87 CARPENTER, TRIAL OF RICHARD DENNIS at 29-30.

88 Id. at 32-39.

89 Id. at 31.

90 The Attorney General from 1792-1808 was John Julius Pringle. Pringle read law under Chief Justice John Rutledge. See 2 O'NEALL supra note 68 at 9 . As noted earlier Rutledge had been educated at Middle Temple. that

91 Simons was one of the leading trial lawyers of the state. One lawyer observed

Mr. Simons had reached a lofty position at the Bar, and his style quite superior to that of his contemporaries, excited even my own boyish admiration. Often did the writer climb to the window of the Court-House, in Charleston, to listen to his impassioned eloquence, charmed and captivated by the force and impetuosity of his speeches.....his method of addressing a Jury was striking and judicious....a voice remarkable for strength and beauty of tone. His enunciation was distinct, and he had a brilliant and ready flow of language. His elocution was a torrent swelled by recent floods, breaking out its natural channels and rushing onward, sweeping all before it.

ONEALL 184-185. Simons studied under Edward Rutledge (Id. at 194) who studied at Middle Temple. 2 O'NEALL 115.

92 These were by Simons, a Mr. Drayton, a Mr. Cheves and Mr. John Ward. Drayton and Cheves were probably William Drayton and Langdon cheves. See 2 O'NEALL

600. The eloquence of Mr. Drayton's closing is shown by this passage:

The great and comprehensive mind of my learned friend, has like the sun, effused such a flood of light upon each topic he has discussed, that it would be vanity in me to think of adding to it-yet as my inferior talents may perchance, like the humble taper, cast a ray upon some object which has escaped the intense blaze of his genius, I venture under every discouragement to offer a few observations; taking all possible care, not to encumber his defence with my assistance, but to comment upon those parts only which he has not touched upon, or if he has, touched upon but lightly.

CARPENTER, TRIAL OF RICHARD DENNIS at 72.

93 CARPENTER, TRIAL OF RICHARD DENNIS at 116. 
In the Joshua Nettles trial, ${ }^{94}$ Carpenter reported "the usual forms on opening a prosecution being gone through," the Attorney General called his first witness. ${ }^{95}$ After the prosecution closed its evidence, John Ward opened for the defense. ${ }^{96}$

The Carpenter reports on these two cases may be the earliest surviving records of full trial proceedings in South Carolina. The only other pamphlet from the first decade of the century is a very incomplete report that recounts little trial procedure and regrets the failure to include all the speeches of counsel.97 A Charleston newspaper account from the 1806 trial of a Colonel Smith did report that counsel for the defense made an opening statement. 98

The one available pamphlet from the next decade reported an 1819 murder trial. ${ }^{99}$ This trial is noteworthy for the speeches by William Lance, Benjamin F. Hunt, and William Crafts, Jr. for the defense, and Attorney-General Robert Y. Hayne for the state. Included are opening speeches by Hayne and Hunt.

After the indictment was read and the jury sworn, the Attorney General, Robert Y. Hayne, began with a strong argumentative speech:

I am called upon, for the first time, to bring to the view of a Court and Jury the circumstances of a foul and unnatural murder.' One of the most valuable citizens, mild, and amiable in his conduct and deportment, pure in his morals, and one of the most spotless reputation, has fallen a victim to the dagger of the assassin! Cut off in the prime of life, in the midst of his usefulness; he has been rudely torn from the embraces of an amiable wife, and numerous and affectionate children, and consigned to the silent tomb. ${ }^{100}$

He also cited Chitty's Criminal Law and other authorities and made a lengthy legal argument, and then he very briefly stated the facts he intended to prove. ${ }^{101}$

94 S. CARPENTER, REPORT OF THE TRIAL OF JOSHUA NETTLES AND ELI CANNON FOR THE MURDER OF JOHN CANNON, ON THE NIGHT OF THE 24TH OCTOBER, 1804 (Charleston, 1805).

95 Id. $5,6$.

96 Ward had been admitted in 1787 (2 O'NEALL 604) and was described as a distinguished and able lawyer. 1 O'NEALL 324.

97 One pamphlet reports a May 10, 1810 trial from Charleston, but includes only a summary of the evidence and the closing speeches of two defense lawyers. The reporter does note at the conclusion of the pamphlet that he regretted his inability to report the "speeches of the Honorable Attorney General" and the speeches of the other prosecution and defense counsel. THE TRIAL OF THOMAS GAYNER FOR THE ALLEGED MURDER OF HIS WIFE (Charleston 1810).

98 South Carolina State Gazette (Charleston), August 16, 1806, at 8. "The counsel for the defendant, after retiring and conferring half an hour returned; when Mr. Colden rose and briefly stated to the jury the nature of the testimony about to be offered in behalf of the defendant. He then said that with the consent of the court, he would proceed to offer that testimony...." 1819).

99 M. STROBEL, TRIAL OF MICHAEL \& MARTIN TOOHEY (Charleston

$100 \mathrm{Id}$. at 4 . Hayne had been admitted in 1812 and studied under Langdon Cheves. 2 O'NEALL 11.

101 Id. 
After the witnesses for the prosecution, Benjamin Faneuil Hunt said "[a]s Counsel for the prisoners, it is my duty to state to you succinctly the grounds of their defence, both in relation to the Law, and the Evidence...."102 After opening fully on the facts and the law, the evidence for the defense began. Following reply witnesses for the prosection, Hunt ${ }^{103}$, William Lance, and William Crafts, Jr. delivered closing arguments for the defense. The reply argument of the Attorney General filled twenty-one pages in the report. ${ }^{104}$

In the criminal libel trial of Lorenzo Dow in $1821,{ }^{105}$ the indictment was read, a not guilty plea entered, the jury sworn, and "[ $t]$ he Attorney General opened the case and stated the law as it will be found in his speech delivered in reply and reported in this trial; he then narrated the facts, and called his witnesses."106 Just before the conclusion of the prosecution's evidence the defendant's lawyer, Samuel Prioleau, made a lengthy argument for the right to put truth in as a defense. ${ }^{107}$ Since he made this argument in front of the jury, he did not deliver an opening speech after the final witness for the prosecution.

Other than the Denmark Vesey slave rebellion trial reports, which contain no mention of counsel speeches ${ }^{108}$, the next available trial comes twenty-three years later in a quo warranto action. The state ex rel. A. Ottolengui vs. G.V. Ancker, and includes the reading of the pleadings and openings statements for both parties. ${ }^{109}$

This 1844 Common Pleas trial before Judge Wardlaw on April 15,1844 was to determine the validity of the claims of competing factions in the Kaal Kadosh Beth Elohim Synagogue. The Attorney General, Henry Bailey, and James L. Petigru represented the state and the plaintiffs. ${ }^{110}$ Mitchell Kingl"I and C. G. Memminger represented the respondents.

102 Id. at 41.

103 The Harvard educated Hunt studied in the office of Keating L. Simons and had much success with juries early in his career. 2 O'NEALL 437 In this trial Hunt succeeded in saving the life of Michael Toohey.

104 Id at

105 TRIAL AND CONFESSION OF LORENZO DOW (Charleston 1821). Charleston Library Society Pm Misc. V. 64, No. 3.

$106 \mathrm{Id}$. at 11-17.

$107 \mathrm{ld}$. at 13-17. Prioleau had studied law in the office of John Ward. 2 ONEALL 324.

108 See J. KILLENS, THE TRIAL RECORD OF DENMARK VESEY (1970). A reprint of the original report entitled "An Official Report of the Trials of Sundry Negroes (Charleston, S.C. 1822).

109 THE STATE EX REL. A. OTTOLENGUI, ET AL. VS. G.V. ANCKER ET AL., REPORT OF THE EVIDENCE AND ARGUMENTS OF COUNSEL BY A MEMBER OF THE CHARLESTON BAR (Charleston, S.C. 1844).

110 Petigru was considered the leading lawyer in South Carolina, and one of the most outstanding lawyers in the country. He had studied law in the office of William Robertson in Beaufort, S.C. and was admitted to the bar in 1812. J. CARSON, LIFE, LETTERS AND SPEECHES OF JAMES LOUIS PETIGRU 37 (1920). Bailey studied law in Petigru's office. 2 O'NEALL 38. 354.

111 King, a native of Scotland, studied law under George Warren Cross. 1 ONEALL 
After the jury was sworn, the Attorney General read the information and Memminger read the Plea of Respondents. 12 " $\mathrm{Mr}$. Memminger claimed the right to open the case, inasmuch as the Respondents were Actors, and maintained the affirmative of the Issue made. After some argument, His Honor settled that Mr. Memminger was entitled to begin. Mr. Memminger then proceeded to lay the case before the Court and Jury."113 What followed was a lengthy statement of the case for the respondents. One contemporary said that Memminger "possessed...the ability to state a proposition and lay a case before a judge or jury as clearly as it could possibly be done." $14 \mathrm{Mr}$. Memminger, having concluded his opening remarks, proceeded to call his witnesses. ${ }^{115}$ When he opened the Attorney General "proceeded to show points to which the crossexamination would be directed." His lengthy speech included such typical phrasing as "We shall show" and "We propose to show".116 After the evidence, Petigru made the closing argument for the relators. King and Memminger closed for the respondents. Then Attorney General Bailey argued in reply. ${ }^{117}$ The state prevailed in the case.

In the 1849 murder trial of Martin Posey in Edgefield, ${ }^{118 "} \mathrm{Mr}$. Bonham stated the case for the Government,"which included introductory remarks followed by "a synopsis of the indictment," but Bonham explained that he would dispense with reading the definitions of the crimes. ${ }^{119} \mathrm{It}$ was further reported "[h]e gave a brief outline of the evidence which he should offer." The witnesses for the prosection followed. The reporter then noted "[t]he prisoner offered no testimony that he might have the closing speech to the Jury, which the mercy of our Law allows, when the accused produces no evidence in his defence. Mr. Carroll requested that three counsel might be permitted to speak in behalf of the prisoner, which gave rise to a discussion that resulted in the Court ruling for the prisoner's right to the opening and closing speech."120

112 Id. at 3.

$113 \mathrm{Id}$. at 4.

114 See Columbia State, Feb. 27, 1893 at 2 quoting Edward McCrady in an biography of Memminger by Henry D. Capers. Memminger was the successor to Petigru as leader of the South Carolina bar. Memminger served as Secretary of the Treasury of the Confederacy.

$115 \mathrm{Id}$. at 10.

116 Id. 17-20. at 57 .

117 After a charge, the jury deliberated and returned a verdict for the relators. Id.

118 REPORT OF THE TRIAL OF MARTIN POSEY, FOR THE MURDER OF HIS WIFE, MATILDA H. POSY, BEFORE THE COURT OF COMMON PLEAS AND GENERAL SESSIONS (JUDGE WITHERS) OF SOUTH CAROLINA, HELD AT EDGEFIELD ON WEDNESDAY, OCTOBER 3, 1849. By A Junior member of the Edgefield Bar (Edgefield, S.C., 1850).

$119 \mathrm{Id}$. at 11.

$120 \mathrm{Id}$. at 40 . The reporter notes here the argument as to "the right to open and close the argument." It is unfortunate that these arguments were not reported. Posey was hanged on February 1, 1850. 
In the 1854 robbery trial of Wiley Morris and Nancy Lay, C.R. Miles for the Attorney General delivered an opening, but it is unclear whether the defense offered evidence or made an opening speech. ${ }^{121}$ The procedure of reading the indictment, opening by the Attorney General and no defense evidence followed by "opening" argument for the defense, was the procedure used in the 1858 murder trial of John Reickles. ${ }^{122}$

In 1857 Major Edward McCardy was court martialed by the South Carolina Militia. ${ }^{123}$ In the proceedings, held in Charleston on March 2, 1857, Major McCardy opened by "stat[ing] briefly the grounds of his defence...." 24 In contrast in the 1859 U.S. Army court-martial of Surgeon B.M. Byrne in Charleston, there were no opening speeches by counsel. The twenty page closing argument of the defense counsel, William E. Martin, was "read to the Court." 25 No prosecution argument was reported. ${ }^{126}$

The last ante-bellum trials for which we have reports are the Echo Cases in federal court. ${ }^{127}$ The indictment was read, followed by the United States District Attorney, James Conner, who "sketched very briefly the laws under which it was proposed to punish the prisoners. In the course of his remarks upon this subject, however, he stated that the question of its constitutionality had been fully and conclusively determined. He stated briefly, also, the main facts which it was proposed to establish, and then called Lieut. C.C. Carpenter, of the United States brig Dolphin." 28 After the evidence for the United States, the defense decided "to rest the point of the case upon argument and argument only, and announced that Maxcy Gregg, Esq., of Columbia, would open the argument." 129

121 Charleston Courier, November 9, 1854, p 1.

122 See J. WOODRUFF, TRIAL OF JOHN H. REICKLES, BEFORE THE HON. D.L. WARDLAW, FOR THE HOMICIDE OF HENRY LINSTEDT, IN THE CITY OF CHARLESTON, TRIED THE 3D AND 4TH JUNE, 1858 (Charleston, S.C. 1858) The attorneys were Attorney General I.W. Hayne and C.R. Miles for the State, and Thomas Y. Simons, Jr., and F.D. Richardson for the Defense.

123 THE TRIAL OF MAJOR EDWARD MCCARDY, JUN., OF THE RIFLE BATTALION, S.C.M. (Charleston 1857).

$124 \mathrm{Id}$. p. 11. This opening is presented as an appendix at $36 \mathrm{Mr}$. Simonton and Mr. Flagg were admitted as counsel on part of the defence, and presented arguments to the Court martial beginning at 22 .

$125 \mathrm{Id}$. at 104.

126 PROCEEDINGS OF A COURT MARTIAL FOR THE TRIAL OF SURGEON B.M. BYRNE HELS AT FORT MOULTRIE ON MARCH 24, 1859 (Charleston 1859). J.S. Woodruff was listed as the "phonographic reporter."

$127 \mathrm{~J}$. WOODRUFF, REPORT OF THE TRIALS IN THE ECHO CASES IN FEDERAL COURT, CHARLESTON, S.C., APRIL, 1859 (Columbia 1859).

$1281 d$. at 7-8.

$129 \mathrm{Id}$. at 10. 
These trial records should establish that the opening speech was the normal procedure in South Carolina on the eve of the Civil War. More conclusive evidence is supplied by South Carolina's first practice manual for lawyers. It was published in 1860 by James Conner, the United States Attorney in the Echo cases and the state's Attorney General after Reconstruction. ${ }^{130}$ In this manual, Conner described a trial thusly:

[T] he plaintiff opens his case by briefly stating to the Court and jury the matters complained of, his legal rights in the case, and the facts he relies on to sustain them; and he then introduces his testimony... The defendant next offers all his evidence in defence and the plaintiff replies, introducing no new matter.... 131

On the eve of the Civil War, Conner makes it clear that the practice in the state was for the plaintiff to deliver an opening statement. He does not report an opening by the defense counsel. However, with one exception all of the available antebellum trial court reports contain opening speeches by the defense counsel whenever evidence was offered by the defense.

\section{POST CIVIL WAR PRACTICE}

The Civil War began a transformation of the bar and its practice. The bar still used the opening speech, but over the next thirty years the use diminished, and by 1890 it had disappeared. These thirty years were turbulent times for lawyers in South Carolina and the rest of the country, and this turbulence distinctly shaped the state's and the nation's legal history. ${ }^{132}$

During the Civil War, the state's legal system came to a standstill. From the ordinance of secession on December 20, 1860 to Lee's surrender in April, 1865, the South Carolina appeals court heard a total of twentyfour cases in law and equity. ${ }^{133}$ Only six of these decisions were from trials during the war, and just three of the appellate decisions were issued during the height of the war, 1862 to 1865.

Although state court practice was stagnant during the war, the wartime military justice system was active. ${ }^{134}$ Undoubtedly many of South Carolina's lawyers were exposed to the military courts and introduced to the procedure of the court martial which as we have seen, substituted the efficiency of reading the specifications of the charge for the opening statement. ${ }^{135}$

$130 \mathrm{~J}$. CONNER, THE HISTORY OF A SUIT AT LAW, ACCORDING TO THE PRACTICE OF THIS STATE, WITH A SKETCH OF THE PRACTICE IN THE COURTS OF THE UNITED STATES FOR SOUTH CAROLINA (2d ed. Charleston 1860).

131 Id. at $25-26$.

132 See K. HALL, THE MAGIC MIRROR 212-25 (1989) and L. FRIEDMAN, A HISTORY OF AMERICAN LAW 295-566 (1973).

133 See 13 Rich. Law and 12 Rich. Eq. (1860-1866).

134 See W. ROBINSON, JUSTICE IN GREY (1941).

135 See trial of Byrne at fn. 126. 
At the end of the war, the enormous loss of life, property, and time had drained South Carolina. Estimates are that nearly twenty five per cent of the draft eligible white male population was killed in the war. ${ }^{136}$ In addition, the state's leading lawyers, James L. Petigru and John Belton O'Neall, had died during the war, and three out of the state's six judges had died and had been replaced between 1861 and 1865. 137

In 1865, Congress tried to prevent those lawyers who had taken up arms against the United States from practicing in the federal courts, but United States District Judge George S. Bryan refused to impose the "test oath" on the South Carolina Bar. ${ }^{138}$ Still the bar could not easily resume the practice of law. Judge A.P. Aldrich's complained in the 1866 trial court opinion of State $v$. Carew, 139 “[m]y library was burned by General Sherman's army when it passed through Barnwell, and I have not had the opportunity to examine the cases submitted."

From 1865 to 1868 a white provisional government tried to maintain control, and, in 1865, promulgated a new constitution. Although the constitution included some reform elements, Professor James L. Underwood has observed that "[f]or the most part [it] was a conservative document crafted by a convention composed of the traditional elites of South Carolina." 140 For example, the constitution ignored the new freedmen except to create for them a separate court system. ${ }^{141}$ Also, this new constitution did not address the codification that James L. Petigru proposed before the war. ${ }^{142}$

For a short time the white provisional government operated side by side with the occupying military. One of the few transcripts from this era is from the 1866 military commission trial of Biggers Mobley, for shooting a former slave. ${ }^{143}$ An Army lieutenant, D.J. Crooks, and Charleston lawyer Alex H. Brown of Porter and Conner represented the prosecution and defense respectively. ${ }^{144}$ The report noted that the

136 See 2 Y. SNOWDEN, HISTORY OF SOUTH CAROLINA 856 (1920).

137 David Wardlaw, Thomas Withers, and Joseph Whitner were replaced by T.N. Dawkins, F.G. Moses, and A.P. Aldrich who were elected in December, 1865. See 13 Rich. Law 3 (1866).

138 See U.R. BROOKS, SOUTH CAROLINA BENCH AND BAR 340 (1908). Also see Files of James Conner (S.C.H.S. Library). The test oath was overturned by the Supreme Court in Ex Parte Garland, 71 U.S. 333 (1866).

13947 S.C.L.(13 Rich.) 498, at 499 (1866). (1989).

1402 J. UNDERWOOD, THE CONSTITUTION OF SOUTH CAROLINA 46

141 S.C CONSTITUTION of 1865 , Article III.

142 See J. PETIGRU, A PORTION OF THE CODE OF STATUTE LAW OF SOUTH CAROLINA (Charleston 1860).

143 See UNITED STATES OF AMERICA VS. BIGGERS MOBLEY, A CITIZEN OF CHESTER DISTRICT-PROCEEDINGS BEFORE A MILITARY COMMISSION, HELD AT COLUMBIA, S.C., (Charleston 1866).

144 Brown had been admitted in 1831. 2 ONEALL 599. 
charge was read, that the defendant pleaded "Not Guilty," but there were no openings. Brown and Crooks read their closing arguments to the Commission. Mobley was convicted.

In contrast, in the 1867 state court murder trial of Horace Greeley and John Bull, after the jury was selected, "Attorney-General Hayne opened the case and said he deemed it necessary to make but a very few remarks,..." 145 At the close of State's evidence, for the first time in the history of the state the criminal defendant was allowed to testify, but also for the first time we find the defense attorneys failing to make an opening before their evidence. 146

In 1868 Congress imposed its Reconstruction upon the state and removed the provisional white government. One of the first acts of the new government was to hold a constitutional convention. The 1868 Constitution was an instrument of reform. It granted full civil rights to all persons regardless of color, abolished debtor's prison, created a public school system, and granted married women the right to control their property. ${ }^{147}$ Its impact on the legal system has been long-lasting. It eliminated life tenure for the judges, forbade their summing up, and created a Supreme Court. ${ }^{148}$ Of greatest impact on law practice was the Jurisprudence section which merged law and equity, imposed a test oath on new lawyers, and directed the General Assembly to codify the statutory law and to revise rules, practice, and pleadings. ${ }^{149}$

To implement codification, the General Assembly created a code commission which proposed a new code of procedure modeled after New York's. ${ }^{150}$ Adopted in 1870, the new code revolutionized civil practice by replacing the common law's myriad replications with "scientific" code pleading.

145 News \& Courier, January 19, 1867, at 2. The article reports that Greeley and Bull were the first blacks to be tried in the Court of General Sessions in South Carolina. J.B. Campbell, R.W. Seymour, and W.E. Mikell were counsel for the defendants, and I.W. Hayne was the Attorney General. Greeley was convicted and Bull was acquitted.

$146 \mathrm{Id}$., January $22,1866 \mathrm{p} .1$. At the close of the defense evidence, the three defense lawyers each made a closing argument followed by the Attorney General.

147 S.C. CONSTITUTION OF 1868, art. I, 1, 20, art. X, 3, and art. XIV, 8.

148 Id. at art. IV.

149 Id. art. $\mathrm{V}, 3$.

150 Statutes of South Carolina, Act 128 (March 9, 1869). The code commissioners were W.J. Whipper from Michigan, D.T. Corbin from Vermont, and Charles W. Montgomery, a native admitted to the S.C. bar in 1859. In part, the new code was based on the code proposed by James L. Petigru as Commissioner of the Code from 1859-1863. On the inside cover of a copy of Petigru's code now in the South Caroliniana Library, Corbin wrote that the volume was used in his work as Code Commissioner. The volume had been loaned to Corbin by Chief Justice F.J. Moses. The notations throughout the volume indicate extensive copying and editing by Corbin. See PETIGRU, A PORTION OF THE CODE OF STATUTE LAW OF SOUTH CAROLINA (Charleston 1860). U. R. Brooks thought that Petigru's code was never adopted (see BROOKS at 137), but Corbin's inscription and notations throughout the volume prove otherwise. 
The primary author of the New York code, David Dudley Field, was an advocate of an efficient trial process, ${ }^{151}$ and the Field Code introduced the innovation of fact pleading. Fact pleading would have provided the jury with a brief, easily understood summary of the case and was more comprehensible than the pre-code pleadings it supplanted. But the new Code did not mention trial procedure and did not eliminate the opening.

Another statute enacted by the radicals may have had a greater impact on opening statements than did code pleading. This statute prohibited lawyers from arguing more than two hours in court. ${ }^{152}$ Since there is no legislative history on this statute, it is difficult to determine the reasons for the limit. Perhaps the legislators shared David Dudley Field's vision of an efficient trial, but anti-lawyer sentiment is also a likely explanation. The provision was part of a statute designed to regulate the bar and included provisions requiring that the new constitutional oath be administered in open court, and prohibiting lawyers from "purchasing or procuring to be purchased any note or other demand for the purpose of putting the same into suit...."153

Anti-lawyer sentiment was common at the time. For example, in the Constitutional Convention of 1868 one delegate said

Let us now consider what class of men would be benefited by the ruin that is threatening the country. First are the lawyers. These are our former politicians.

These are responsible for the unjust laws we have always had. These are responsible more than any other one class for secession and the ruin which has attended it.

But the argument limitation had little immediate impact. It was ignored in many trials ${ }^{155}$, and was liberally interpreted in others to permit a two hour period for each lawyer. ${ }^{156}$

The 1868 Constitution not only changed the legal system, but also impacted the bar through the test oath. ${ }^{157}$ This oath required all bar applicants to swear that they would protect and defend the Constitutions of the United States and South Carolina. Many Confederates could not or would not take such a pledge. The oath appears to have slowed admissions dramatically. ${ }^{158}$ For example, in 1866 ninety-three men were

151 In the 1885 report by Field and John F. Dillon on "Delay in Judicial Administration" to the American Bar Association, Field did complain that "[n]o sooner is the trial opened than a wordy debate begins." REPORT OF THE EIGHTH ANNUAL MEETING OF THE A.B.A. 338 (1885). But Field did not specifically call for the elimination of the opening.

152 STATUTES OF SOUTH CAROLINA, Act \# 46 (Special Session 1868).

153 STATUTES OF SOUTH CAROLINA, Act \# 46, 4 and 7 (Special Session 1868).

154 PROCEEDINGS OF THE CONSTITUTIONAL CONVENTION OF SOUTH CAROLINA 120 (reprinted 1968).

155 See e.g. the trial reported by the Columbia Daily Register, April 5, 1881, p.4.

156 State v. Jones, 29 S.C. 201, 232 at fn. I (1888).

157 S.C. CONSTITUTION art. II, 30 (1868).

158 The ROLL OF ATTORNEYS of the South Carolina Supreme Court records the following admissions: 1866- 72(law) 21(equity); 1867-32(law) 17(equity); 1868-18(law) 13 (equity);1869-4;1870-3;1871-15; 1872-6; 1873-13; and 1874-14. However, after 1868 these records may not be complete because the Circuit Courts were permitted to admit lawyers to practice before it and the Probate Court. See 1868 Stat. of S. C., Act No. 46 (Sept. 23,1868 ). 
admitted to either the law or equity bars, and in 1869 only four were admitted to the merged bar by the Supreme Court.

In 1867 a law school was established at South Carolina College 159 and graduated at least 7 blacks before being closed in 1877.160 Since admission records of the Supreme Court do not identify lawyers by race, it is difficult to know with certainty, but estimates are that twelve blacks were admitted to the bar during Reconstruction, and that fiftysix blacks were admitted between 1868 and 1915. ${ }^{161}$ In addition to the blacks, a number of the new members of the bar and the judiciary during Reconstruction were from outside the state. 162

Reconstruction had a dramatic impact on the judiciary. Radicals were elected to the Supreme Court, including Jonathan J. Wright, a black. Although no blacks served as circuit court judges during Reconstruction, ${ }^{163}$ the entire circuit court bench was replaced and expanded. Twenty-one different men served in the eight circuit judgeships from 1868 to 1876.164 In contrast, among the sitting circuit judges at the start of the Civil War the shortest length of service was fourteen years. ${ }^{165}$

Despite code pleading, the limitations on lawyer speeches, the revolving judiciary and the new elements in the bar, the opening statement was still used during Reconstruction. Case reports available from this era include twenty-five newspaper accounts and three partial transcriptions of civil trials. Three 1868 accounts do not mention the

159 See 2 D. HOLLIS, U.S.C. COLLEGE TO UNIVERSITY 37-38 (1956).

160 Commencement Bulletins 1873-1877, U.S.C. Archives. For identification of race see T. HOLT, BLACK OVER WHITE, 299-412 (1977) AND J. WILLIAMSON, AFTER SLAVERY: THE NEGRO IN SOUTH CAROLINA DURING RECONSTRUCTION 223, 233 (1975).

161 Oldfield, "A High and Honorable Calling: Black Lawyers in South Carolina, 1868-1915," 23 JOURNAL OF AMERICAN STUDIES 395 (1989) (Printed in Great Britain).

162 For example, in addition to the non-native code commissioners, Supreme Court Chief Justice Amiel J. Willard was from New York (BROOKS at 36), Justice Jonathan Wright was from Pennsylvania (BROOKS at 68) Justice Solomon Hoge was from Ohio (BROOKS at 66), Circuit Judge Robert Carpenter was from Kentucky (BROOKS at 167, Circuit Judge Zephania Platt was from Pennsylvania (BROOKS at 168), and Circuit Judge Pierce L. Wiggin was from New Hampshire (BROOKS at 227).

163 Actually one black, William J. Whipper, was elected to a circuit judgeship. When he was elected one newspaper declared "Civilization in Peril." Charleston News and Courier, Dec. 24, 1875 at p. 1. Whipper was denied his judgeship by a Supreme Court decision holding that the sitting Judge J.P. Reed's term had not expired even though Reed had been elected to replace a deceased judge whose term had expired. See Whipper $v$. Reed, 9 S.C. 5 (1877).

164 See title page of volumes 1-10 of the South carolina Reports for the period 1868 to 1877 .

165. The sitting cinuit judges in 1860 were J. N. Whitner who died in 1864 , Thomas Glover and Robert Munro. See 13 Rich. Law 3 (1866). Glover and Munro served until 1868. See 15 Rich. Law 3 (1869). Their elections to their circuit judgeships were in 1850, 1852 and 1853. See 2 O'NEALL 597. 
initial procedure of the trial. 166 Two 1869 criminal trials included opening remarks by the prosecution, but none by the defense. ${ }^{167}$ From 1871 and 1872 , the transcripts of three civil cases from the files of James Conner include references to counsel for the plaintiff opening the case before the introduction of evidence. ${ }^{168}$ In the retrial of one of these cases the handwritten transcription reports, "Mr. Tharin opened by stating to the jury the whole circumstances of the case."169

In two criminal trial reports from 1873 , the solicitor made opening statements, but in two others there are not enough details to determine whether openings were delivered. ${ }^{170}$ In the 1874 retrial of one of these cases there is no mention of the solicitor's opening, but the defense's opening statement by long- time Charleston lawyer R.W. Seymour was reported. ${ }^{171}$ The closing arguments included a three hour summation by the Attorney General plus speeches by the Solicitor and three defense counsel. ${ }^{172}$ Another 1874 criminal case included openings statements by both the prosecution and the defense. ${ }^{173}$

In nine 1875 reports, one recorded openings for both prosecution and defense, two reported defense opening statements, two included just

166 Charleston Daily Courier, January 25, 1868, p. 2, January 27, 1868, p. 2, and January 29,1868, p. 2 .

167 The trial of James F. Walsh, Daily Courier, February 11, 1869, p.1 and the trial of two black soldiers, Charleston Daily Republican, Sept. 17, 1869, p. 1. In the $1871 \mathrm{Ku}$ Klux Klan trials in Columbia only the prosecutor delivered an opening statement. After government's evidence, the defense simply followed with its evidence. Since the defense was handled by two prominent out of state lawyers, former United States Attorney Generals Reverdy Johnson and Henry Stanberry, we can assume that the defense strategy of not making an opening argument was common practice throughout the country. PROCEEDINGS IN THE KU KLUX KLAN TRIALS AT COLUMBIA S.C. (United States Circuit Court, November Term, 1871.) (Reprinted 1969).

168. James Conner Papers, S.C. Historical Society Library, File Box 28-200. Partial transcript of record in Anna Eliza Gilbert, admx. of Jas. Gilbert, deceased vs. S.C. R.R., (April, 1871); File Box 29-199-17, partial transcript of Michael Waters against S.C. R.R., (May, 1871); and File Box 29-199-handwritten transcription notes from Michael Waters against S.C. R.R., (February 26, 1872).

169 Id. Michael Waters v. S.C. R.R. (February 26, 1872).

170 News and Courier, Feb. 11, 1873 p. 1 ("the Solicitor OPENED THE CASE by saying....") (emphasis in original); Solicitor Brawley had been admitted in 1866. BROOKS 351. News and Courier, June 18, 1873 p. 4. ("In opening the case, the solicitor stated...."); News and Courier, June 20, 1873 p. 4. (no openings); News and Courier, Nov. 11,1873 p. 4. (No openings reported). C.W. Buttz, the Solicitor in these last three cases, was admitted in 1872. See Roll of Attorneys.

171 News and Courier, Feb. 4, 1874. p. 4. News and Courier, Feb. 6, 1874, p. 4. "Col. R.W. Seymour submitted, in advance, the grounds for the defence. He addressed the jury upon the importance of considering the case impartially, and free from the influence of public opinion." Seymour had been admitted in 1823. See 2 ONEALL 603.

172 Id.

173 News and Courier, Feb. 12, 1874, p. 4. "The solicitor on opening the case explained to the jury the nature of the indictment and the various counts...." Id. After reporting the conclusion of the evidence for state "Mr. Barker, one of the counsel for the defence, then opened the defendant's case, calling attention of the jury to the flimsy character of the evidence upon which so grievous a charge as that of murder was based." Then the witnesses were called. Id. Feb. 13, 1874, p. 4. 
the indictments, in two others, the defense waived their right to present evidence and gained the right to reply, and in one of five incomplete reports the case went to the jury without any arguments. ${ }^{174}$

In six 1876 reports there is one prosecution opening and one defense opening, and one case in which the defense waived the right to present evidence to gain the reply argument. ${ }^{175}$

In 1877 "white Democratic control of the government was attained through a violent overthrow of the Republican Party" by General Wade Hampton and his followers. 176 The end of Reconstruction brought dramatic changes. All but one of the circuit judges were replaced by 1878. ${ }^{177}$ The Supreme Court had two new justices by 1877 and an another in 1880 . However, only eleven men served as circuit judges from 1877 to 1890 , bringing some stability to the bench.

Soon the bar rolls began to swell. During Reconstruction the Supreme Court had admitted only 112 lawyers; in contrast 538 new lawyers were added from 1876 to 1886 . Only $36 \%$ of the lawyers on the rolls of the South Carolina Bar Association in 1885 had been admitted before $1860 .{ }^{178}$ In fact, there were only 315 lawyers in practice in the state on the eve of the Civil War, ${ }^{179}$ while four hundred lawyers were admitted in the first half of the 1880's alone. ${ }^{180}$ Almost all of these new lawyers were white, but when the Hampton government closed South Carolina College, Allen University opened a law school which operated from 1880 to 1898 and produced at least 17 black South Carolina lawyers. ${ }^{181}$

174 News \& Courier, April 21, 1875 p. 1 (opening by D.T. Corbin for state and defense opening by H.A.M. Smith in the Dawson libel trial), February 11, 1875, p. 4, February 12, 1875 p. 4, February 13, 1875, p. 4, February 17, 1875, p. 4, May 19, 1875 , p. 3 (brief defense opening by W.F.B. Haynsworth), June 10, 1875, p. 4.

175 News \& Courier, February 16, 1876 p. 4, February 22, 1876, p. 4, February 24,1876 , p. 4 , February 25,1876 , p. 4 (defense opening by Seabrook), February 26, 1876, p. 1 (only Solicitor Buttz opened), February 29, 1876, p. 4.

176 Richard Mark Gergel, "Wade Hampton and the Rise of One Party Racial Orthodoxy in South Carolina," 77 PROCEEDINGS OF THE SOUTH CAROLINA HISTORICAL SOCIETY 5(1977). After the election both sides claimed victory. Hampton succeeded under the "great compromise" of 1876 which cast South Carolina's electoral votes for Rutherford B. Hayes for President in exchange for the removal of federal troops in April of 1877.

177 The lone survivor was T.J. Mackey, who had campaigned for Hampton. See BROOKS at 196-202.

178 There were 212 members of the bar association in 1885 and of those only 77 could have been admitted before the war. Compare TRANSACTIONS OF THE FIRST ANNUAL MEETING OF THE SOUTH CAROLINA BAR ASSOCIATION (1885) with 2 O'NEALL.

179 See Williams, "The Criminal Lawyer in Ante-Bellum South Carolina," 56 S.C.H.M. 138, 142 (1955). The Supreme Court records show 779 admissions from 1861 to 1885. See ROLL OF ATTORNEYS.

180 See ROLL OF ATTORNEYS for 1880-1885.

181 See Oldfield at 399. 
The greatest number of black bar admissions came between 1876 and 1895.182 One study of the General Sessions Dockets in Charleston County determined that black lawyers handled 33 per cent of the cases in 1882, and 28 per cent in 1886 . $^{183}$

At the beginning of the Hampton era the opening was still being utilized but primarily by the older members of the bar. Several prosecutions of Reconstruction officials for corruption illustrate this point. Three of these trials were in 1877. In the Trial of F.L. Cardozo, Attorney-General James Conner prosecuted. Of course, Conner had practiced before the war and had written the 1860 treatise, The History of a Suit at Law, which described the opening as a brief statement of "the matters complained of, of his legal rights in the case, and the facts he relies on...." Conner opened the Cardozo trial with "a brief statement of the case against Cardozo...."184 Samuel W. Melton did not open for the defense. Melton had been admitted in 1857. 185

In Congressman Robert Smalls' trial on November 9, 1877, a lawyer of forty years experience, Leroy $F$. Youmans, ${ }^{186}$ opened by presenting "the case in form, stating the law, the indictment, and what the State expected to prove." 187 After the state closed, the defendant declined to open and rested without calling any witnesses. Robert Carpenter and S.W. Melton represented Smalls. Carpenter had been a Union army officer and a Reconstruction era circuit judge. ${ }^{188}$ This case may indicate that some lawyers placed a greater emphasis on the closing arguments, as the defense by waiving the right to present evidence obtained the right to make the final rebuttal argument, and both defense lawyers made closing arguments. 189

Six 1878 trial reports contained no openings by either party. ${ }^{190}$ But three articles reported that closing arguments were waived by both sides. ${ }^{191}$ The diminishing role of the opening in criminal cases continued in a highly charged murder trial from Edgefield in 1879. The Booth and Toney trial began with the formalism of reading the indictment without opening speeches by any of the lawyers. ${ }^{192}$ After the defense

182 Oldfield at 396-397.

183 Oldfield at 402 n. 32.

184 News and Courier, November 2, 1877, p. 1

1852 O'NEALL 610.

186 Youmans was admitted in 1836. 2 O'NEALL 604.

187 News \& Courier, November 10, 1877 at p. 1.

188 BROOKS at 167.

189 In a related case the News \& Courier reported the November 13, 1877 of trial of L. Cass Carpenter for bribery in which it noted that "the solicitor stated the case to the jury in few words, and..." called the first witness.

190 News and Courier, June 4, 1878, p. 4, Id.; June 5, 1878, p. 4, Id., June 7, 1878 , p. I; Id. June 8, 1878, p. 4; and Id., June 11, 1879, p. 1.

191 News and Courier, June 4, 1878, p. 4 (State v. Hamilton and State v. Bell), and News and Courier, June 7, 1878, p. 1 (State v. White).

192 TRIAL OF BOOTH AND TONEY (Augusta 1881). 
finished its evidence, beginning with the prosecution and alternating, three lawyers for each side made closing arguments. ${ }^{193}$ Of the nine lawyers participating only two had been admitted before the war. ${ }^{194}$

But the bar had not fully abandoned the opening speech. In a March, 1880 murder case at Walhalla, "Colonel Cothran, the Solicitor, opened the case, briefly telling the jury [what] the State expected to prove...." 195 There was no report of an opening by the defense prior to the call of their witnesses. But after the close of the evidence, W.C. Keith ${ }^{196}$ for the defense argued for three hours, and "[h]e was followed by Major John B. Moore, of Anderson, for the prisoner, in an able speech. Solicitor Cothran closed for the State." 197 In another case from the same term of General Sessions, the newspaper reported no openings, but the closings were briefly noted. ${ }^{198}$

This mixed practice was repeated in 1881. In the February 24, 1881 trial of W. B. J. Cash for killing William Shannon in a duel, Leroy Youmans delivered an opening. ${ }^{199}$ The article reported:

The attorney-general [Youmans] addressed the jury, explaining the cause of his action in the case. He believed that the State could not do better by delay and the accused was anxious for trial. He explained the three possible verdicts, murder, manslaughter and acquittal. Should either of the two latter verdicts be proved just he proclaimed that none would rejoice more than the prosecuting officers of the State, but the Court would charge that killing in duel was murder, and while making reasonable allowance for questions of fact, they must bring in a verdict of murder.

After the witnesses testified, the defense offered no evidence. The jury could not reach a verdict, and the Court declared a mistrial. No openings were reported in the June retrial which acquitted Cash. ${ }^{200}$ Youmans did not participate and Solicitor George W. Dargan represented the state. 201

193 Id. at p. 248.

194 For the state, Solicitor John B. Abney was admitted in 1875, John C. Sheppard was admitted in 1873, Ernest Gary was admitted in 1875, and M.W. Gary was admitted in 1855 . For the Defense, M.C. Butler was admitted in 1857, R.G. Bonham was admitted in 1877 and C.L. Woodward's date is unknown. See ROLL OF ATTORNEYS. Orlando Sheppard may have been admitted in 1875. See 1 CYCLOPEDIA OF EMINENT AND REPRESENTATIVE MEN OF THE CAROLINAS 275 (1892).

195 Daily Register, March 4, 1880 at p. 4. James S. Cothran was admitted in 1853. See BROOKS at 267.

196 Keith had been admitted in 1859. See Daily Courier, December 1, 1859, p.2.

197 Daily Register, March 5, 1880 at p. 1. James S. Cothran had been admitted in 1854. See 2 O'NEALL at 607. John B. Moore had been admitted in 1859. See 2 ONEALL at 611 .

198 Daily Register, March 9, 1880, p.1.

199 News \& Courier, Feb. 24, 1881, p.1. "The Cash-Shannon Duel- Trial of Col. E.B.C. Cash in Darlington for Murder".

200 News and Courier, June 22, 1881 p. 1 and June 23, 1881, p. 1.

201 A J. George Dargan from Darlington was admitted in 1866. See ROLL OF ATTORNEYS. 
In the 1881 Priester trial in Barnwell there were no openings by the state or the defense. ${ }^{202}$ The newspaper account reported that "[t]he solicitor [F.H. Gantt] arraigned the prisoner, reading the indictment in a deep and solemn voice. The prisoner pleaded not guilty." ${ }^{203}$ And after the jury was sworn the State called its first witness.

The available reports from 1882 are too sketchy from which to draw any conclusions, but the inconsistent practice continued in 1883. In a trial in Newberry County, no openings were reported; 204 however, in a murder trial in Columbia, D.A. Straker, a black law professor at Allen University, "asked to be permitted to address the jury as to the line of defense which would be adopted, and if to do so would deprive him of the right of argument after the testimony had been submitted...."205 Judge J.H. Hudson said he could make a "statement of the points intended to be set up for the defense and what was expected to be proven by the testimony, but it would not be in order to present argument to the jury at the time...", and Straker outlined his defense. ${ }^{206}$ After the evidence, Straker and the solicitor made closing arguments. ${ }^{207}$

Straker 208 had studied law at Howard University. His inquiry as to the right to give an opening demonstrated either ignorance of the proper procedure, the solicitude of the deferential black lawyer before the white judge, the absence of a common practice, or the requirement of judicial approval before delivering an opening. He was Dean of the Allen University Law School from 1882-1887. Considering his later career in Michigan it is unlikely that ignorance of procedure caused his inquiry. ${ }^{209}$. According to newspaper accounts Straker was an aggressive advocate for his clients, and was not afraid to publicly criticize a judge or whites. ${ }^{210}$

202 News and Courier, June 11, 1881.

203 Id. Gantt had been admitted in 1856. See 2 O'NEALL at 608.

204 Columbia Daily Register, February 5, 1883, at p. 4. (Trial of U.B. White for failing to turn over public monies to his successor) The report does not mention openings nor jury selection but does report evidence for prosecution and then reports "No testimony was offered for the defense. This gave the defense the right to open and close the argument. Mr. O.L. Schumpert made the opening argument in a speech of nearly an hour; he was followed by the Solicitor; Mr. Pope closed for the defense. The Solicitor and Mr. Pope spoke about thirty minutes each." There was a mistrial. O.L. Schumpert was admitted in 1874. See ROLL OF ATTORNEYS.

205 Daily Register, April 4, 1883, p. 4

206 Id.

207 Id. April 5, 1881 p. 4. "At the conclusion of the evidence Mr. Straker made an ingenuous and able argument of over two hours and a half, in which he analyzed with great skill the testimony offered in the case, and by the application of the propositions laid down by the medical journals and authorities on the subject of homicides under the influence of insanity, built up a strong argument in favor of the theory of homicidal insanity for the defense."

208 See Oldfield, at 395-406.

209 Straker brought one of the first successful civil rights cases in Michigan. See Ferguson v. Gies, 82 Mich. 358 (1890). See also D. KATZMAN, BEFORE THE GHETTO 18994(1973), and A. BLOOMFIELD, AMERICAN LAWYERS IN A CHANGING SOCIETY: 1776-1876 337-39 (1976).

210 See Daily Register, January 8, 1887, p. 1 which published a letter from Straker accusing a judge of mistreating black tenants. Also see Daily Register, July 7, 1883, p. 1 which published a letter by Straker defending himself against racist threats and allegations of trial misconduct. 
Since there is no other report of a lawyer seeking judicial approval of the right to open, the most logical explanation for Straker's request was that the local practice was in a state of flux.

Judge Hudson seemed to be speaking of an opening much like that of today. He wanted the opening to be brief, factual and non-argumentative. Admitted to the bar in 1857, Hudson practiced law, except for war service, until he was elected circuit judge in 1878 where he served until 1894, but we know little of his judicial philosophy. ${ }^{21 !}$ In another case before Hudson during the same term of General Sessions, the newspaper account seems to indicate that the solicitor made a brief opening statement to the jury. ${ }^{212}$ In the only available criminal case from 1884, the indictment was read, but no openings were reported. ${ }^{213}$

In 1885 , there were a number of criminal trials reported, but no opening statements by the state were included. ${ }^{214}$ However, one article summarized the indictment and the opening statement by the defense. ${ }^{215}$ In another the reading of the indictment was reported without any reference to openings. ${ }^{216}$ In three other 1885 cases, the reports are too incomplete to determine whether the indictments were read or any openings were made. 217

In the 39 criminal cases found from 1884-1891 there are no opening statements reported for either defense or prosecution. However, the reading of the indictment was reported in five cases and closing arguments reported in all but eight cases. By the mid-1880's the opening statement had been abandoned by the criminal trial bar.

The abandonment of the opening statement was slower in Common Pleas cases. In 1884 in an article, captioned the "Columbia Scandal," the News \& Courier reported the slander suit of McDaniel vs. Bruce. The article noted "Mr. Fickling [plaintiff's counsel] made an opening address, stating what he expected to prove...." ${ }^{218}$ But there was no opening by the defense. 219

$211 \mathrm{He}$ was forced to return to private practice by the Tillman revolution. In his autobiographical sketch in U.R. Brooks' SOUTH CAROLINA BENCH AND BAR, Hudson reveals that he graduated number one in his class at South Carolina College in 1852, but his legal education was from his own reading from January, 1857 to May, 1857. Little is revealed in his sketch about his judicial career other than that he worked hard and that he never carried a case home but decided the cases during term time and in open court. See also J.H. HUDSON, SKETCHES AND REMINISCENCES (1903).

212 Daily Register, April 6, 1883 at p.4.

213 News and Courier, Nov. 18, 1884 p. 6

214 Id., February 9, 1885, p. 1; Feb. 21, 1885 p. 1; March 22, 1885, p. 1.

215 Id., March 9, 1885, p. 1. The article reported that " $[t]$ he defense, briefly states, is that both the parties were highly intoxicated and that the killing was in self defense."

216 Id., March 20, 1885, p. 1.

217 See $1 d$., February 21 , 1885, p. 1 .

218 Id., November 19, 1884, p.2.

219 Id. November 22, 1884, p.1. 
Fickling had been admitted in 1838; both defense counsel had been admitted after the war. ${ }^{220}$ In the 1887 case of Sanders $v$. Sanders, ${ }^{221}$ the court's opinion notes that the pleadings were read.

The next year, an opening statement was reported in the McCrady vs. Robertson libel trial. 222 The plaintiff was represented by ex-Attorney General C.R. Miles, who had been admitted in 1851,223 and the defendant was represented by Col. John T. Sloan, Jr, who had been admitted after the war. ${ }^{224}$ The newspaper reported that after reading the complaint, Miles continued

by saying the action was for the publication by the defendant of a false and scandalous libel. He alluded to the plaintiff being known to the jury as having rendered service in war as a gallant soldier; in peace as a legislator and a lawyer of the first rank of the profession; as a gentleman of culture and education, and as a consistent Christian of good standing.

After more than fifty years of respected life he has been stigmatized as a perjurer and a scoundrel, and for what? His conduct of a case in which he had not a dollar of personal interest, and because in his professional conduct of that case it had been his duty to resist the defendant's plans.

Miles continued with some of the facts of the case but soon returned to his rhetoric:

If the defendant had assaulted the plaintiff with a bludgeon and beaten and bruised him, what general indignation would have been aroused! Should there be less because he had attacked him in something more dear to every man than anything else! If he had struck him down with a bludgeon it would have been soon over; but the plaintiff had infused poison into his blood and sought to break down this stainless gentleman and send him out as a perjured villain.

The account of Miles' opening continued for nearly one and a half full newspaper columns. Sloan opened the defense merely by reading the defendant's "answer". After reading the answer, the examination of witnesses began. There were full closings for both plaintiff and defense. ${ }^{225}$ McCrady was awarded $\$ 2,500.226$

By the end of the 1880's the opening had disappeared from the criminal trial and was virtually unheard in civil trials, and the bar continued to

220 For Fickling. See 2 O'NEALL at 608. W.H. Lyles was admitted in 1878. See ROLL OF ATTORNEYS. Andrew Crawford was admitted in 1871. HISTORY OF THE RICHLAND COUNTY BAR 68 (1948).

22130 S.C. 207 (1887).

222 Daily Register, April 17, 1888 at p. 4.

223 See 2 O'NEALL 611.

224 John T. Sloan was one of three students in the first law class at South Carolina College admitted in 1867. He and Arthur Moore were the first graduates on June 29, 1868. Sloan was a student for only nine months, and studied under law professor Alexander C. Haskell who "developed his own system of conducting his juniors through a course of Blackstone's Commentaries and his seniors through one on Stephen's Pleadings." See 2 HOLLIS, 37-38. Alexander C. Haskell was admitted to the Bar in 1865. He served on the Supreme Court from 1877-1879. See BROOKS at 70-71.

225 Daily Register, April 25, 1888 at p. 4.

226 Id. April 27, 1888, p. 4. 
change. Between 1866 and 1900, the Supreme Court admitted 1296 lawyers. 227 Of the new 525 admissions between 1886 and 1900, 131 had graduated from the Law School at South Carolina College.228 Graduates of South Carolina College of Law, Allen University and other law schools constituted nearly thirty per cent of the total admissions by the end of the century. 229

In 1890 another upheaval caused additional changes in the judiciary and legal system. The farmers' movement led by Benjamin Tillman had elected him governor in 1890. The chief objective of the movement was to empower the farmers, and its chief tactic was to attack Hampton and the so-called aristocrats as being out of touch with modern times. ${ }^{230}$ Consequently, the judiciary became a target, and all but one circuit court judge were replaced by 1896; a Supreme Court majority favorable to Tillman was achieved in the same year. ${ }^{231}$ In 1895 another constitution had been adopted. This constitution added another justice to the Supreme Court and limited its appellate power on constitutional questions. ${ }^{232}$

After 1890, the opening statement cannot be found. In the 1892 Lester $v$. Kendall libel case the complaint and answer were read by counsel, but there were no opening statements. ${ }^{233}$ Two other civil case reports from 1892 included no mention of openings or reading of the pleadings. ${ }^{234}$ Similarly, eight criminal cases from 1892 to 1896 contained no openings. ${ }^{235}$

No systematic search has been made of the records after 1895, but the files of one prominent Columbia lawyer, B.L. Abney, were examined. These files cover the period from 1895 to 1917. Abney's files contain more than a dozen transcripts or handwritten notes from both civil and criminal cases. In none of these cases is there an opening statement mentioned. The pleadings were read in the civil cases, and the indictments were read

227 See ROLL OF ATTORNEYS.

228 See ROLL. OF ATTORNEYS and the Commencement Bulletins and enrollment records of U.S.C. for 1885-1900. (U.S.C. Archives.)

229 There were 17 blacks admitted from Allen. Oldfield supra note at 399. At least twelve other lawyers graduated from out-of-state law schools. James Coke Klugh, Robert O. Purdy, and B.L. Abney graduated from the University of Virginia Law School. George Gage graduated from Vanderbilt. See U.R. BROOKS, SOUTH CAROLINA BENCH AND BAR. Andrew Crawford attended the University of Virginia Law School. See HISTORY OF THE RICHLAND COUNTY BAR 68 (1948). Stiles Dendy, John McLaurin, Richard Wylie, J.K.P. Goggans, and James L. Orr, Jr. graduated from Virginia. Ernest Moore graduated from Washington and Lee, and Abraham Levi graduated from Albany. See 1 CYCLOPEDIA.

230 See WALLACE, SOUTH CAROLINA- A SHORT HISTORY, 614-629 (1951).

231 Compare list of judges at 34 S.C. iii (1890) with 47 S.C. iii (1896).

232 S.C. CONSTITUTION OF 1895 , art. V.

233 State, April 23, 1892, p. 2.

234 Id., April 16, 1892 p. 8.

235 Id., April 2, 1892 p. 8; April 6, 1892, p. 2., March 30, 1893, p. 2; March 31, 1893 , p. 8; April 11, 1893 p. 8; Daily Register, Oct. 15, 1895, p.1 ; Feb. 21, 1896, p.3; April 14, 1896 p. 3. 
in the criminal cases. ${ }^{236}$

After 1900, not even the most notorious trials began with opening statements. In the 1903 trial of Lieutenant-Governor James Tillman for the murder of N. G. Gonzales, editor of The State newspaper the prosecution began with the reading of the indictment followed by the testimony of the first witness. ${ }^{237}$

After 1900 jurors did not hear an opening statement in a state court until after World War II. A 1909 graduate of the University of South Carolina Law School, Grover C. McLaurin, recounted that it was simply not practice to deliver an opening statement and that it did not occur to lawyers to use it. ${ }^{238}$ United States Circuit Judge Donald Russell, a 1928 graduate, said that he had never heard of giving an opening statement in state court until after World War II and described having to read the pleadings as "awful."239 The late David W. Robinson, who was admitted in 1922, remembered it as simply custom to read the pleadings and believed that the practice came about from lawyers being "too lazy" to prepare and deliver an opening. 240 These and other anecdotal accounts of lawyers who practiced in this period are uniform in remembering that lawyers simply did not make opening statements. ${ }^{241}$

236 Files of Col. B.L. Abney, South Caroliniana Library (U.S.C.). (The Abney files are unindexed; therefore, citation can be only to a box.) (Box 7) Transcript of Pelzer Manuf. Co. vs. Hamilton Cely, Aug. 28, 1893. "The pleadings were read."; (Box 9) Transcript of unnamed Common Pleas trial, Sept. 8, 1898 "pleadings read."; Transcript of State vs. Southern Railway Co., Nov. 29, 1910, p.6 "The bill of complaint was read to the jury by Mr. Welch and the Attorney General." "The answers of the defendant were read to the jury by Col. Abney."; (Box 11) Transcript of A.G. Clarkson vs. Southern Railway Co., Dec. 21, 1908 "The complaint was read by attorney for plaintiff."; (Box 12) Handwritten notes of "memo of evidence" in State v. Boykin. Towill \& Co., Undated but possibly 1910-11. "Jury sworn." "Indictment read by Atty. Genl to jury. Witnesses sworn."; (Box 17) Transcript of Gallman v. Glenn Springs Railway Co., October 12th, 1904, "Pleadings Read."; (Box 26) Letter of May 5, 1906 to Charles K. Oliver, Treasurer, Mt. Vernon-Woodberry Cotton Duck Co., Baltimore Maryland, Re: Birdie Bledsoe by her Guardian ad Litem vs. Columbia Mills Co. Letter recounts jury trial of April 30, 1906 before Hon. D.E. Hydrick and only summarizes pleadings.; (Box 27) Transcript of L.A. Krelland H.E. Taylor vs.Southern Railway Co., June 27, 1901 "Complaint read by Plaintiff 's attorney."; Handwritten notes of Burnett v. Pelzer Manuf. Co. trial. "pleadings read." ; (Box 30) Transcript of Mary Chambers v. A.G. Bookman, Sept. 8, 1898, "Pleadings read"; (Box 32) Transcript of Gillery Martin vs. Columbia Mills Co., October 11, 1917, "Pleadings Read."; and (Box 40) Henry M. Williams and Monnie Williams against Columbia Mills Co. and S.P. Venson, November Term, 1913, p. 14 of transcript notes after call of case, selection and swearing of jury "pleadings read."

237 Lexington Dispatch, September 30, 1903, p. 4.

238 Interview with Grover C. McLaurin, Sr. on July 31, 1989.

239 Interview with the Honorable Donald Russell, August 1, 1989.

240 Interview with David W. Robinson, Jr, on August 2, 1989.

241 Interviews with Honorable Joseph R. Moss (7-25-89); Arthur A. Rittenburg (8-1-89); Edward W. Mullins (8-3-89), Raymond McElveen (7-3I-89); J. Carlisle Oxner (7-26-89); Frank Sloan (5-8-89); Augustus T. Graydon (5-15-90); Thomas H. Pope (520-90); Edward A. Harter (8-7-90). Letters from E. Lloyd Willcox (8-22-89); O. Frank Thornton (7-28-89); Malcolm C. Woods, Jr. (7-27-89). 
In 1959 the Circuit Court Rules for the first time recognized the court's authority to prohibit openings and limit lawyers to reading their pleadings. ${ }^{242}$ In 1985 the Rules were amended to allow the opening statement - some 95 years after its abandonment by the bar. ${ }^{243}$

\section{WHY WAS THE OPENING ABANDONED?}

The empirical evidence establishes that the opening statement was brought to South Carolina by English-trained barristers and remained an integral part of the jury trial until the 1880 's. Then it disappeared. Normally a change in the law, substantive or procedural, is the direct result of an appellate decision, court rule, or legislative enactment. But the opening was not banished in South Carolina by court decision, court rule or legislative enactment. Therefore, the disappearance must be attributed to other factors.

The most likely source for change in South Carolina trial procedure would have been the Code of Procedure adopted in 1870. But the Code of Procedure did not mention opening statements, and it did not apply to criminal trials where the opening first disappeared. By 1900 twentyeight states and Alaska had adopted the Field Code, ${ }^{244}$ but the opening statement was recognized and used in almost all of these states. Only South Carolina, North Carolina, and Connecticut of the twenty-eight appear to have cast aside the opening. ${ }^{245}$

Code pleading was not without impact. ${ }^{246}$ The chief attribute of

242 Rule 85, Rules of Practice for the Circuit Courts, 1952 SOUTH CAROLINA CODE OF LAWS (Supp. 1960).

243 See South Carolina Rules of Civil Procedure, Rule 43(g) (1985) which is titled "Statement of Pleadings to Jury."

244 Reppy, "The Field Codification Concept," DAVID DUDLEY FIELD: CENTENARY ESSAYS, 17, at 45 fn. 143 (1949).

245 Also one non-code state, Rhode Island, has had no published decisions on the opening statement. The early bar of Rhode Island used the opening. See State $v$. Dorr, 2 Am. State Trials 2 (1844). Today in Rhode Island the opening is permitted by rule in criminal cases(R.I. Super. R. Crim P. 26.2 (Adopted 4-26-72)), and in civil cases the practice is permitted under the right to open and close. Interview with Robert Barge of the Rhode Island bar (July 17, 1991). See Rhode Island Super. R. Civ. P. 43 (h) (1) (1991). There are no indications that Rhode Island's bar ever adopted the practice of reading the pleadings, and lawyers today say that they have always had the right to make an opening statement.Interviews with Robert Barge and Alden Harrington of Providence, Rhode Island (July 17, 1991).

246 The order of proof and argument in a trial was the subject of nine decisions by the South Carolina Supreme court in the 1880's, but none of these cases addressed the right to make an opening speech prior to the evidence nor did any of these cases address the impact of code pleading. Bennett $v$. Sandifer, 15 S.C. 418 (1880) Kennedy v. Moore, 17 S.C. 464 (1882). Boyce v. Lake, 17 S.C. 481, 484 (1882); Burkhalter v. Coward, 16 SC 435, 441 (1882); McConnell v. Kitchens, 20 S.C. 430 (1883); Mitchell v. Fowler,21 S.C. 298 (1884); State v. Huckie, 22 S.C. 298 (1884); Roach v. Kentucky Co., 28 S.C. 431, 436 (1887); Sanders v. Sanders, 30 S.C. 207 (1887). Also in 1882, the Supreme Court amended its Rule 59 on the right to open and reply, adding "The party having the opening in an argument, shall disclose his entire case; and on his closing, 
code pleading was the requirement that the plaintiff plead "a plain and concise statement of the facts constituting a cause of action...."247 The words of the statute promised more clarity than the pleadings of practicing lawyers delivered. The complaints were filled with legal jargon and formalistic allegations. ${ }^{248}$ The answers of the defendants were even worse, being filled with denials of "each and every allegation" of the complaint. ${ }^{249}$

The promise of code pleading is also seductive in suggesting that it induced the lawyers to substitute the pleadings for the opening speech. But reading the pleadings was not new. The former practice was to read the pleadings and make an opening speech, and in fact, we found the pleadings being read in the early $1400^{\prime}$ '. ${ }^{250}$

Another Reconstruction era statute was the time limitation on lawyer arguments. Of course, this statute did not directly address the right to make an opening speech, but the limitation applied equally to the opening and closing. Many lawyers viewed the closing argument as much more important than the opening speech and it would be natural to assume that they simply decided to use their time only in closing. ${ }^{251}$ But, the evidence from numerous trials does not necessarily support this. The fact is that many lawyers ignored the limitation. Also, statutory or court-imposed time limits on arguments were common in the late nineteenth century, but such limits did not result in the abandonment of the opening speech in other states. ${ }^{252}$

shall be confined strictly to a reply to the points made and the authorities cited by the opposite party." R.W.SHAND, A MANUAL CONTAINING THE CONSTITUTION OF SOUTH CAROLINA, THE RULES OF COURT AND THE FEE BILL JULY 1,1882 (1882).

Under the common law, a defendant could plead the general issue, thus placing on the plaintiff the burden of proof on all issues. Under code pleading, the general issue's equivalent, the general denial, was much less useful because pleadings had to be verifted, making it very difficult to deny all of the allegations in the complaint. Therefore, defendants had to admit upon the record many of the allegations of the complaint, and having done so, began to assert that they had the burden of proof and consequently the right to open and close. See Huntington v. Conkey, 33 Barb. 218 (1860).

247 See H. LIGHTSEY, CODE PLEADING 76 (1976).

248 The first paragraph from a complaint drafted by B.L. Abney's office in 1904 reads as follows:

The plaintiff, complaining, alleges:

1. That it is now and was on the dates hereinafter mentioned a corporation duly chartered and organized by and under the laws of the State of South Carolina, and as such is doing business in the city of Columbia, Richland county, with its business office located in said city, state and county. That the Defendant, G.A. Guignard, is a resident of the county of Lexington.

Abney Files (Box 1).

249 See answer in Transcript of A.G. Clarkson v. Southern Railway Co., (Dec. 21, 1908). Abney Files (Box 11).

250 HORN, supra note 15 at $47-48$.

251 See J. REED, PRACTICAL SUGGESTIONS FOR THE MANAGEMENT OF LAW-SUITS 220 (1876).

252 People v. State, 122 Mich. 284, 81 N.W. 107 (1899); Lindsey v. State, 138

Ga. 818, 76 S.E. 369 (1912); and State v. Varnado, 131 La. 952, 60 So. 627 (1913). 
But South Carolina was not alone. Both North Carolina and Connecticut abandoned the opening speech, and both states had statutorily imposed time limits on arguments. North Carolina's limit was two hours. ${ }^{253}$ Connecticut's limit was one hour. ${ }^{254}$ North Carolina's abandonment of the opening followed a similar pattern to that of South Carolina. ${ }^{255}$ Connecticut's abandonment was not as complete, because for most of the twentieth century, Connecticut has seen a limited use of the opening statement. ${ }^{256}$ But even today some judges in Connecticut require lawyers to read their pleadings in lieu of making an opening speech. 257

253 See State v. Campbell, 14 N.C. App. 596, 188 S.E. $2 d 558$ (1972).

254 State v. Hoyt, 47 Conn. 518 (1880).

255 The early North Carolina trial records contain opening speeches. State $v$. Carawan, 6 Am. State Trials 514 (1853); and State v. Cherry and Thompson, 3 Am. State Trials 562 (1873). As late as 1883 the North Carolina Supreme Court said it was a long-standing practice in the state for the attorneys to make an opening speech. State v. Sheets, 89 N.C. 543, 547 (1883). Sometime after 1883 the North Carolina bar also abandoned the opening speech. By the 1940's the lawyers read their pleadings to the court. Interview with Associate Justice Harry C. Martin of the North Carolina Supreme Court (June 17, 1991); Interview with Judge Sam J. Ervin III of the United States Court of Appeals (June 18, 1991). Also see Privette v. Privette, 230 N.C. 52, 51 S.E.2d 925 (1949). The reading of pleadings in civil cases was the "general practice" (Jackson v. Jones, 159 S.E.2d 580 (N.C. App. 1968)) until it was banished by rule in 1967. See reporters comments to Rule 7(d), N.C. Rules of Civil Procedure, N.C.G.S. 1A-1. The right to make an opening in a criminal case was not re-established until 1978; however, some commentators thought the 1978 rule established the right to make an opening for the first time. Van Camp and Gill, "The Trial", 14 W.F.L. Rev. 949 (1978).

256 This right to make an opening statement has been in the discretion of the trial judge. Interview with Hon. Robert C. Zampano, Senior Judge, U.S. District Court for the District of Connecticut, 7-23-91. Also see U.S. v. 5 cases more or less, 179 F.2d 519 (2d Cir. 1950), cert. denied 339 U.S. 963 (1950). In 1920 in civil cases there was a practice of allowing the attorneys to make introductory remarks to the entire venire before selection of the jury. See Oc Connor v. Zavaritis, 95 Conn. 111, 110 Atl. 878 (1920). Some judges made the opening statement. Gray v. Mossman, 91 Conn. 430, 99 A. 1062 (1917). In 1929 one Connecticut lawyer commented that one difference between the English and Connecticut practices was the use of the opening address in England. Hewes, "English Procedure," 3 CONN. B.J. 13 (1929). But in 1940 one Connecticut judge criticized lawyers for reading their pleadings and said he preferred an opening statement. See Jennings, "How to try a Case in the Trial Court's from a Judge's Point of View," 14 CONN. B.J. 112 (1940). In 1978, Connecticut adopted a rule for civil cases that provided that "[i]nstead of reading the pleadings, counsel for any party shall be permitted to make a brief opening statement...." Conn. Superior Ct. R. of C.P. 296 (1978). There is no right to make an opening statement in criminal cases in Connecticut because the opening is strictly discretionary with the judge. State v. Ridley, 7 Conn. App. 503, 509 A.2d 546 (Conn. App. 1986).

257 Interviews with William Clendenen of New Haven, Connecticut (7-18-91) and Steve Weisner of New Haven, Connecticut, (7-19-91). 
There is no evidence that the practice of the bars of North Carolina, or Connecticut had any impact on South Carolina practice. ${ }^{258}$ Other states also placed limits on the openings speech. In Florida, Alabama, and Tennessee the privilege of making an opening statement was solely within the trial judge's discretion. ${ }^{259}$ However, the lawyers in all three states used the opening statement. ${ }^{260}$

Most significantly, the opening speech was being transformed throughout the country. The opening speech that the early American lawyers delivered to juries had been that of the English barrister, one of passion and argument. But over the course of the nineteenth century in the United States the opening became a speech in which the lawyers simply stated what they intended to prove. Argument was banned.

The trend began in New York, ${ }^{261}$ and was soon followed in other states. By 1900 the opening speech had been transformed from an argument to a statement, but it was not abolished. ${ }^{262}$ To the contrary,

258 Amazingly as late as 1949 one South Carolina judge wrote in the South Carolina Law Quaterly that South Carolina's practice of reading the pleadings was unique. Lide, "Some Uniques' in South Carolina Law," 1 S.C.L.Q. 209 (1949)

259 Stewart v. State, 245 Ala. 511,17 S.2d 871 (1944); Henderson v. State, 158 Fla. 684, 29 S.2d 698 (1947); and Graham v. Cloar, 30 Tenn. App. 306, 205 S.W.2d 764 (1947).

260 See Wilkey v. State, 238 Ala. 595, 192 S. 588 (1939); Thalheim v. State, 38 Fla. 169, 20 So. 938 (1896); and Fey v. Nashville Gas \& Heating Co., 16 Tenn. App. 234, 64 S.W.2d 61 (1933).

261 Ayrault v. Chamberlain, 33 Barb. 22 (N.Y. 1860)

262 See McFalls v. State, 66 Ark. 16, 48 S.W. 492 (1898); People v. Williams, 43 Cal. 344 (1872); Emmerson v. Weeks, $58 \mathrm{Cal}$ 382, (1881); Jones v. Baltimore, etc. R. Co., 16 D.C. 8 (5 Mackey's Rep.) (1885); Thalheim v. State, 38 Fla. 169, 20 So. 938 (1896); Sterling v. State, 89 Ga. 807, 15 S.E. 743 (1892); Metropolitan St. R. Co. v. Johnson, 90 Ga. 500, 16 S.E. 49 (1892); Giffen v. Lewiston, 6 Idaho 231, 55 P. 545 (1898); McDonald v. People, 26 Ill. 150, 18 N.E. 817 (1888); Aylesworth v. Brown, 31 Ind. 270 (1869); Willey v. State, 52 Ind. 421 (1876); Zimmerman v. State, 4 Ind.App. 583, 31 N.E. 550 (Ind.App. 1892); Frederick v. Gaston, 1 G. Greene 401 (lowa, 1848); State v. Meshek, 61 Iowa 316, 16 N.W. 143 (1883); Lindley v. A.T. \& S.F.R. Co., $47 \mathrm{Kan} .432,28 \mathrm{Pac} .20 \mathrm{I}$ (1891). O'Brien v. Commonwealth, $89 \mathrm{Ky} .354,12 \mathrm{~S} . \mathrm{W}$. 471 (1889); State v. Coolidge, 3 Am. State Tr. 732 (Me. 1848); Maxfield v. Jones, 76 Me. 135 (Me. 1884); State v. Grasty et al, 5 A.S.T. 216 (1893); State v. Gruber, 1 AST 69 (1819); Davis v. Calvert, 5 Gill \& J. 269, 25 Am.D. 282 (Md. 1833); State v. Crockett, 1 Am.State Tr. 440 (1835); Howe v. Dickinson, 154 Mass. 494, 28 N.E. 910 (1891); Scripps v. Reilly, 35 Mich. 371, 24 Am.R. 575(1877); State v. James, 11 AST 661 (1883); State v. Childs, 2 Am. State Tr. 205 (1849); State v. Boogher, 8 Mo.App. 599 (1880); Vaulter v. Hultz, 112 Mo. 633, 20 S.W. 689 (1892); Stewart v. Hamilton, 3 Rob. 672 (N.Y.); State v. Weeks, 1 Am. State Tr. 1 (1800); People v. Van Zile, 73 Hun. 534, 26 N.Y.S. 390 (1893); State v. Blake, I Am. State Tr. 825 (1816); State v. Smith, 1 Am. State Tr. 779 (1817); State v. Witlenburgh, 1 Am. State Tr. 361 (1817); State v. Taylor, 61 N.C. 508 (1867); State v. David, 49 N.C. 353 (1857); Churchhill v. Lee, 77 N.C. 341 (1877); State v. Young, 212 N.W. 857, 55 N.D. 194 (1927); Keim v. Maurer, 2 Woods 412 (Pa.); Nesbitt v. Turner, 155 Pa. 429, 26 A. 750 (1893); State v. Eaton, 5 Am. State Tr. 910 (1868); Morales v. State, I Tex.App. 494, 28 Am. Rep. 419 (1877); Holsey v. State, 24 Tex.App. 35, 5 S.W. 523 (1887); U.S. v. Sprague, 8 Utah 378, 31 Pac. 1049 (1893); People v. Chalmers, 5 Utah 201, 14 Pac. 131 (1887); Wis. Haley v. Western Transit Co., 76 Wis. 344, 45 N.W. 16 (1890); Kelley v. Troy Fire Ins. Co., 3 Wis. 254 (1854); Baker v. State, 69 Wis. 32, 33 N.W. 52 (1887); Hall v. Needles, 1 Ind.T. 146, 38 S.W. 671 (Okla. 1897). 
the opening statement was well established in almost all of the states. ${ }^{263}$

One might assume that the opening was transformed out of fear that an argumentative opening speech would infect the fact-finding function of the jury. But the chief cause of the limitations appear to have been counsel using inadmissible evidence in their openings. ${ }^{264}$ Although a number of the cases concluded that the opening was limited none articulated prejudicial impact of argument as the reason. ${ }^{265}$ In South Carolina there was only one nineteenth century case addressing the issue of improper argument by counsel and the court found no basis upon which to reverse the jury's decision. 266

A more significant influence on the demise of the opening speech was the fashion of the period, which was efficiency. Oratory had become old-fashioned. In 1912, a Missouri lawyer complained that speeches by lawyers were growing too short, and that oratory was "rapidly

263 Loeb v. Webster, 213 Ala. 99, 104 So. 25 (1925); Ragsdale v. State, 132 Ark. 210, 200 S.W. 802 (1918); Scarborough v. Central Ariz. L \& P Co., 58 Az. 51, 117 P.2d 487 (1941); Bias v. Reed, 169 Cal. 33, 145 P. 516 (1914); Burke v. South Boulder Canon Ditch Co., 76 Co, 354, 231 P. 674 (1924); Pritchard v. Henderson, 19 Del. 128 (3 Pennewill 128), 50 A. 217 (Del.Sup. 1901); Robertson v. Washington Ry \& Electric Co., 51 App.D.C. 311, 279 F. 180 (1922); Allen v. Hooper, 126 Fla. 458, 171 So. 513 (1937); Ridley v. Ridley, 102 S.E. 918 (Ga. App. 1920); State v. McClurg, 50 Id. 762, 300 P. 898 (1931); Pietsch v. Pietsch, 245 Ill. 454, 92 N.E. 325 (1910); Vandalia Coal Co. v. Butler, 68 Ind.App. 245, 119 N.E. 34 (Ind.App. 1918); Lamp v. Lannegan, 188 N.W. 982 (Iowa 1922); Glenn v. Mo. Pac. Ry. Co., 87 Kan. 391, 124 P. 420 (1912); aff'd on reh., 88 Kan. 235, 128 P. 362 (1912); Louisville Gas Co. v. Ky. Heating Co., 132 Ky. 435, 111 S.W. 374 (1908); State v. Ricks, 170 La. 509, 128 So. 293 (1930); State v. Morin, 126 Me. 136, 136 A. 808 (1927); Stocksdale v. Jones, 133 Md. 176, 104 A. 416 (1918); Com. v. Tucker, 189 Mass. 457, 76 N.E. 127 (1905); People v. Swift, 172 Mich. 473, 138 N.W. 662 (1912); St. Paul Motor Vehicle Co. v. Johnston, 127 Minn. 443, 149 N.W. 667 (1914); Collins v. State, 99 Miss. 52, 54 So. 666 (1911); State v. Lewkovitz, 265 Mo. 613, 178 S.W. 58 (1915); Downs v. Cassidy, 47 Mont. 471, 133 P. 106 (1913); Yechout v. Tesnohlidek, 97 Neb. 387, 150 N.W. 199 (1914); State v. Olivieri, 236 P. 1100,49 Nev. 75 (1925); Hoxie v. Walker, 75 N.H. 308, 74 A. 183 (1909); Kelly v. Bergen Co. Gas Co., 74 N.J. Law 604, 67 A. 21 (1907); State v. McDonald, 152 P. 1139, 21 N.M. 110 (1915); Sweeney v. O'Owyer, 197 N.Y. 499, 90 N.E. 1129 (1910); State v. Young, 212 N.W. 857, 55 N.D. 194 (1927); Cincinnati St. Ry Co. v. Adams, 33 Ohio App. 311, 169 N.E. 480 (Ohio App. 192)); Kali Inla Coal Co. v. Ghinelli, 55 Okla. 289, 155 P. 606 (1916); Lane v. Portland Ry., Light \& Power Co., 58 Or. 364, 114 P. 940 (1911); Oland v. Kohler, 111 Pa. Super. 185, 169 A. 411 (1934); Smith v. Groesbeck, 54 S.D. 350, 223 N.W. 308 (1929); Fey v. Nashville Gas \& Heating Co., 16 Tenn.App. 234, 64 S.W. 2d 61 (Tenn.App. 1933); Watson v. Watson, 229 S.W. 899 (Civ.App. 1921); State v. Erwin, 101 Utah 365, 120 P.2d 285 (1941); Williams Mfg. Co. v. Insurance So. of N. Am., 93 Vt. 161, 106 A. 657 (1919); Matthews Lumber Co. v. Lincoln Furniture Mfg. Co., 148 Va. 413, 139 S.E. 254 (1927); Schmitz v. Kirchan, 32 Wash. 546, 73 P. 678 (1903); State v. Barrick, 60 W.Va. 576, 55 S.E. 652 (1906); Wiesenbach v. State, 138 Wis. 152, 119 NW. 843 (1909); and Nicholson v. State, 18 Wy. 298, 106 P. 929 (1910).

264 See Scripps v. Reilly, 35 Mich. 371 (1877). Cf. Mosier v. Stoll, 20 N.E. 752 (Ind. 1889) holding that conclusions in the opening are permissible.

265 See Ayrault v. Chamberlain, 33 Barb. 230 (N.Y. 1860).

266 State v. Robertson, 26 S.C. 117 (1887). 
becoming a thing of the past...," due to the impatience of the modern juror. ${ }^{267} \mathrm{~A}$ more logical explanation is that the bar and the judiciary changed. As illustrated by the $\mathrm{McDaniel}$ and $\mathrm{McCrady}$ trials in the 1880's, the antebellum lawyers, Fickling and Miles, delivered opening speeches. But in both cases, the post-war lawyers did not make opening speeches, and one, John Sloan, used the modern efficiency of reading the pleadings.

The style of oratory changed over the course of the nineteenth century. Abraham Lincoln's Gettysburg address of two minutes is legendary for its brevity and eloquence, while Edward Everett's two hour oration is unknown. ${ }^{268}$ Brevity in speech was becoming the modern trend in trial practice. ${ }^{269}$ One commentator said it was "a violation of good taste to mingle the statements of cold facts with the ornaments of rhetoric...."270 At first the new style was viewed with suspicion in South Carolina. ${ }^{271}$ But as the bar changed, its view of oratory changed. John Belton O'Neall's Bench and Bar of South Carolina, published in 1859, described a bar of eloquence. Admitted in 1814,272 O'Neall cited numerous examples of the early bar's oratory. These descriptions indicate more than an author's interest in oratory. Similarly, B.F. Perry, who practiced from 1827 to 1886 , marbled his reminiscences of the pre- war bar with comments on their speaking abilities. ${ }^{273}$

In contrast, U.R. Brooks' 1903 Bench and Bar of South Carolina described a bar that rose out of the adversity and the humiliation of the war and Reconstruction. Brooks' sketches are as likely to include comments on the hard work and earned wealth of the subject as com-

267 Williamson, "Disappearing Argument," 21 YALE L. J. 489, at 490 (1912).

268 See ABRAHAM LINCOLN: THE GETTYSBURG ADDRESS AND AMERICAN CONSTITUTIONALISM 15 (de Alvarez ed. 1976).

269 JOHN C. REED, PRACTICAL SUGGESTIONS FOR THE MANAGEMENT OF LAW-SUITS, 220, 337 (1876); 1 S. THOMPSON AND M. EARLY, A TREATISE ON THE LAW OF TRIALS, 276 (1912).

2702 B. ELLIOTT AND W. ELLIOTT, A TREATISE ON GENERAL PRACTICE, 688 (1894).

271 An 1882 federal voting fraud trial in Columbia (U.S. v. Bates) illustrates that some lawyers saw the modern style to be foreign. A Philadelphia lawyer was brought in to help try the case. The lawyer, Dallas Sanders, gave a short closing argument and the reporter noted the

disappointment of a host of able admirers in the rear of the court room when he sat down. Mr. Sanders was either handicapped with the weakness of his case or else his friends had largely overestimated his powers as a speaker. He had a style peculiar to himself and one which is rarely if ever exhibited outside a school room. The Court seemed to feel some compassion for Mr. Sanders and when he got through, in answer to an inquiry of surprise on the part of Mr. Haskell if Mr. Sanders had got through, Judge Bond remarked that the lawyers of Philadelphia were not in the habit of making such long speeches as the Charleston lawyers, and that business was too brisk there for a display of eloquence.

Columbia Register, April 15, 1882. p. I.

272 See 2 O'NEALL 611.

273 See 2 PERRY supra note 89. 
ments on his oratorical skills. The obituaries of the bar at the turn of the century provide a similar view. In South Carolina Bar Association obituaries between 1885 and 1903, the deceased's financial success was one of the most significantly mentioned items in over a third of the careers memorialized. In fact, one 1889 obituary complained that there was "evidence that the members of the Bar are now conducting the profession as a business - as one might conduct a grocery store-for the money to be made in it...."274 In half of these obituaries there was no mention of oratorical skills. In a collection of biographies of leading citizens of the state published in 1892 , the contrast between the prewar and postwar bars is even more striking. ${ }^{275}$ The oratorical skills of the antebellum lawyers was almost an historical curiosity. Of the biographies of sixty-three prewar lawyers, seventeen mentioned oratory or the ability to persuade a jury. Of sixty-six post war lawyer biographies only four mentioned oratory or the ability to persuade a jury.

The postwar biographies placed more significant emphasis on the business interests or practice of the lawyers. Financial success was mentioned at least a dozen times in the postwar biographies. The biographies of forty five lawyers admitted after the war mentioned representation of corporate, railroad or other business clients. For example, Benjamin H. Moss, who had been admitted in 1883, was a lawyer from the small town of Orangeburg, but nonetheless was identified as a specialist in "banking, corporation and commerical law."276 Many of these postwar lawyers were bank presidents, or were on the board of the local mill; or even founded significant industrial enterprises.

B.L. Abney, the Southern Railway's lawyer, was one of the most prominent and important lawyers in the state at the turn of the century. As his files reveal, he probably never made an opening speech to a jury. In fact he participated in few trials. He simply parceled out the work to other lawyers. In 1909 he had fifty-eight lawyers working under him for Southern Railway. 277 Abney was one of the first corporate lawyers in South Carolina, but other leading lawyers such as William S. Brawley 278 and Joseph W. Barnwell 279 were also corporate lawyers. The dominance of the corporate client and the profit motive for law

274 TRANSACTIONS OF THE FIFTH ANNUAL MEETING OF THE SOUTH CAROLINA BAR 106-107 (1889).

2751 CYCLOPEADIA OF EMINENT MEN AND REPRESENTATIVE MEN OF THE CAROLINAS-NINETEENTH CENTURY (1892).

276 Id. at 270.

277 Id. (Box 1) 1909 Southern Railway Annual Passes for local counsel.

278 See BROOKS 351.

279 See Huff, "Urban Bourbon: Joseph W. Barnwell and the Search for a New Aristocracy," 1981 PROCEEDINGS OF THE SOUTH CAROLINA HISTORICAL SOCIETY 133. 
practice drew complaints from some bar leaders, ${ }^{280}$ but modern practice was firmly established.

The bar changed as a result of growth, diversity, and education. The lawyers were concerned with making money. The clients with money were corporations concerned with efficiency. Consequently, law practice had to become more efficient.

The demise of the opening was hastened by other factors also, such as the instability of the judiciary and the increased demands on the judges. The trial level judiciary was virtually replaced in toto five separate times between 1860 and 1895 . The Supreme Court's membership was replaced three times in its first thirty years. The legal system came to a halt during the war. Then the Supreme Court's caseload grew by triple from Reconstruction to the 1880 's. ${ }^{281}$ The litigation explosion was indicative of the new economic order which saw the industrial revolution and capitalism make their mark on the state, and again, these were factors that called for more efficiency.

\section{CONCLUSION}

The opening was a victim of the social and economic revolution that engulfed South Carolina and the United States after 1860. As Karl Llewellyn has observed, "[w]ith us fifty years can re-create the whole notion of the legal universe." 282 While no one factor can be cited as the cause for the abandonment of the opening, one may conclude that it was seen as an inefficient tool for the modern lawyer equipped with telephones, electric lights, and typewriters.

The story of the opening statement in South Carolina illustrates the long neglect of the history of trial practice, and the folk wisdom basis of much of its purported history. Now that some of that history is known, there are many questions that need fuller discussion and debate.

This history suggests that the development of the brief factual

280 See address of President Charles Richardson Miles,TRANSACTIONS OF THE FIFTH ANNUAL MEETING OF THE SOUTH CAROLINA BAR ASSOCIATION, p. 38 (1889) (complained about the increased competition.); Address of President Henry E. Young, TRANSACTIONS OF THE SIXTH ANNUAL MEETING, p. 66 (1890) (complained about the corporations commanding the best talent.); and Address of Thos. M. Raysor, TRANSACTIONS OF THE SEVENTH ANNUAL MEETING, p. 61 (1891) (complained "that the great mass of its members are becoming mere men of business, real estate negotiators and brokers, managers of corporate and other enterprises rather than lawyers...."

281 During the nine years of Reconstruction, the court issued 565 decisions. In the first nine years after Reconstruction the court issued 1,562 decisions. Cf. Vols. 19 of S.C. Reporter with vols. 10-32.

282 K. LLEWELLYN, JURISPRUDENCE 218 (1962). 
opening as we know it today in the United States was the more the result of fashion than of reasoned development. The opening statement is strictly limited throughout the United States. Should it be limited? Should argument be permitted? Should lawyers be allowed to discuss their legal theories? Should an opening be restricted to only a brief summary of the facts? Should its length be regulated? Should lawyers be allowed to use demonstrative aids and exhibits? There is no explicit right to make an opening speech in criminal trials in many states. Should the judges have complete discretion over the right of the criminal defendant to have his defense explained to the jury?283 Should the right to make an opening statement be protected by the Constitution??284

We now know that for nearly three hundred years lawyers have made opening speeches to juries in South Carolina and the other states. It is hoped that this article has uncovered enough of the early history of opening statements to establish a context in which to answer some of these important questions.

283 State v. Brown, 277 S.C. 203, 284 S.E.2d 777, 778 (1981).

284 In United States $v$. Salovitz, the court held that the opening statement did not exist at common law in 1789 and therefore, there was no right to an opening statement by a criminal defendant's counsel. Supra note 3. Also see Lucas, "Opening Statement," 13 U. HAW. L. REV. 349 (1991) and Note, “Opening Statement: A Constitutional Right?," 7 AM. J. TR. ADVOC. 623 (1974). 